\title{
UNIVERSITY OF PENNSYLVANIA RADIOCARBON DATES IX
}

\author{
ROBERT STUCKENRATH, JR., WILLIAM R. COE, and \\ ELIZABETH K. RALPH \\ Department of Physics and University Museum \\ University of Pennsylvania, Philadelphia, Pennsylvania 19104
}

\section{INTRODUCTION}

This date list includes those series of samples completed in this laboratory as of November, 1965. The B.P. ages are based upon A.D. 1950, and are calculated with a half-life value of $5568 \mathrm{yr}$. Errors quoted are those derived from measurements of sample, background, and modernage calibration, and do not include any half-life error. All samples were pretreated with $3 \mathrm{~N} \mathrm{HCl}$, and some, where noted, received additional pretreatment with $2 \% \mathrm{NaOH}$ for the removal of possible humic contaminants.

Standard calibration samples are 110- to 125-yr old oak samples which, when corrected for age, have $\mathrm{C}^{14}$ contents equal to $95^{\circ} \%$ of the NBS oxalic-acid standard. The $\mathrm{C}^{13}$ relationship between the oak standard and NBS limestone standard \#20 is $-25.7 \pm 1.3 \%$ as measured on the University of Pennsylvania mass spectrograph.

\section{SAMPLE DESCRIPTIONS}

I. ARCHAEOLOGIC SAMPLES: NEAR EAST

\section{Agrab Tepe series, Iran}

\section{A. Iran}

Agrab Tepe (37० N Lat, $45^{\circ} 28^{\prime} \mathrm{E}$ Long), is located near Hasanlu Tepe in Solduz Valley of Azerbaijan Prov. of Iran. Coll. 1964 and subm. by R. H. Dyson, Jr., director of joint expedition of Univ. Mus., Univ. of Pennsylvania, Metropolitan Mus. of Art of New York City, and Archaeol. Service of Iran. These samples are all representative of Hasanlu Period IIIA (Pennsylvania III, VI, IX) .

P-895. Period IIIA, Section C, floor

Charcoal from floor of Section C, Period IIIA.

P-894. Period IIIA, Section A

Large lumps of charcoal, Section A, Period IIIA.

P.980. Period IIIA, Section D, center

Charcoal and clay from center of room, section D, Period IIIA. Comment: $\mathrm{NaOH}$ pretreatment.
$2665 \pm 54$

715 B.C.

$2582 \pm \mathbf{5 5}$

632 B.C.

$2540 \pm 56$

590 B.c. 
P.979. Period IIIA, Section D, W wall

Charcoal from Section D, against W 507 B.c. $\mathrm{NaOH}$ pretreatment.

P-879. Period IIIA, burned beam

$2391 \pm 54$ ment: $\mathrm{NaOH}$ pretreatment. Roots present.

P-893. Period IIIA, reeds

$2289 \pm 47$

Charred reeds from Section A, Period III Comment: $\mathbf{3 3 9 \text { B.c. }}$ treatment. Roots present.

\section{Hasanlu Tepe series, Iran}

Hasanlu (37 $\mathrm{N}$ Lat, $45^{\circ} 28^{\prime} \mathrm{E}$ Long), is located near town of Nagadeh in Azerbaijan Prov. of Iran, about halfway between Nagadeh and $S$ shore of Lake Urmia, just $S$ of small freshwater lake known as Shor Gol or Hasanligut. Coll. 1962 and subm. by R. H. Dyson, Jr., Director of the joint expedition of Univ. Mus., Univ. of Pennsylvania, Metropolitan Mus. of Art of New York City, and Archaeol. Service of Iran. Samples in this series represent Grey Ware phase (Hasanlu Period IV), represented by spouted pitchers, which was ended by sacking of the site, an event perhaps fitting historically with a known Urartian campaign in the area at end of 9th century в.c.; and Triangle Ware phase (Hasanlu Period III) which is thought to date to end of Median period. late 7th century B.c. (Dyson, 1958, 1959, 1960a, 1960b, 1962; Pennsylvania III, VI).

\section{Grey Ware Phase (Periods IV, IVB)}

P.905. Period IV, gate building $2700 \pm 54$ Period IV. Comment: NoOH pretreatment.

\section{P-862. Period IV, under Tower 5}

$$
2665 \pm 46
$$

Charcoal from floor under Tower 5 , Period IV. Comment: $\mathbf{7 1 5}$ B.c. pretreatment.

P-906. Period IV, gate building floor

$$
2648 \pm 54
$$
Charred grain, on floor of gate building of Burned Building
Period IV. Comment: NaOH pretreatment. Compare P-905, above.

\section{P-860. Period IVB}

$$
\mathbf{2 7 1 8} \pm \mathbf{5 5}
$$

768 B.C.

Charred grain mixed with charred reeds, on floor $S$ of oven in Burned Building III, Period IVB. Comment: $\mathrm{NaOH}$ pretreatment. 
P-907. Period IVB, grapes

749 B.C.

Dried grapes from vase on floor of Burned Building III, Period IVB, believed to date sacking of site.

P-861. Period IVB, floor

$2627 \pm 53$

677 B.c.

Charred grain on floor of Burned Building III, Period IVB. Comment: $\mathrm{NaOH}$ pretreatment.

P-863. Period IVB, near grindstone

$2604 \pm 55$ Burned Building III, Period IVB. Comment: $\mathrm{NaOH}$ pretreatment.

P-865. Period IVB, citadel

$2529 \pm 53$

579 в.c.

Charred wheat from Floor 3 of citadel, Period IVB. Comment: $\mathrm{NaOH}$ pretreatment. Sample undersized.

Triangle Ware Phase (Period III)

$2521 \pm 52$

P-903. Period III, Pit 7

571 B.C.

Charred grain from Pit 7, associated with human skull, Period III.

P-866. Rezaiyeh Road Tepe, Iran

$5445 \pm 72$

3495 B.c.

Charcoal from "Rezaiyeh Road Tepe $\left(37^{\circ} 40^{\prime} \mathrm{N}\right.$ Lat, $45^{\circ} 30^{\prime} \mathrm{E}$ Long), $79 \mathrm{~km} \mathrm{~N}$ of Hasanlu Tepe, near Geoy Tepe and town of Rezaiyeh, Azerbaijan, Iran. Coll. 1962 and subm. by R. H. Dyson, Jr., Univ. Mus., Univ. of Pennsylvania. Comment: sample from stratum containing materials resembling those of early Pisdeli Tepe levels; compare P-157, $4560 \pm 160$ (Pennsylvania III); P-505, $5638 \pm 85$; and P-504, 5518 \pm 81 (Pennsylvania VI).

\section{P-931. Tall-i-Bakun B, Iran}

$6264 \pm 70$

Ash from point in wall of Japanese trench at Tall-i-Bakun $\left(30^{\circ} \mathrm{N}\right.$ Lat, $52^{\circ} 50^{\prime}$ E Long), on Marv Dasht plain near Fars, SW of Persepolis, Iran. Associated with coarse straw-tempered pottery. Coll. 1964 and subm. by J. R. Caldwell, Illinois State Mus., Springfield (Langsdorf and McGown, 1942). Comment: compare P-438, $5990 \pm 81$ (Pennsylvania VI) from approx. same point in this mound.

\section{P-930. Tall-i-Ghazir, Levels 5 and 6}

$7762 \pm 98$ 5812 B.c.

Ash from Levels 5 and 6 of a step trench excavated by D. E. McCown in 1948 at Tall-i-Ghazir ( $31^{\circ} 20^{\prime} \mathrm{N}$ Lat, $49^{\circ} 29^{\prime}$ E Long), $13 \mathrm{~km}$ NW of Ram Hormuz, Khuzistan, Iran. Coll. 1964 and subm. by J. R. Caldwell (McCown, 1955; Caldwell, mss.). Comment (J.R.C.): sample 
should date upper range of painted buff ware at this site, and is believed contemporary in part with Susa A, and no earlier than LeBreton's "d" (1957). Date is apparently $2000 \mathrm{yr}$ too old.

\section{Tal-i-Iblis series, Iran}

Tal-i-Iblis (29 $51^{\prime} \mathrm{N}$ Lat, $56^{\circ} 41^{\prime} \mathrm{E}$ Long), lies in Mashiz Valley, $12 \mathrm{~km} \mathrm{SE}$ of Mashiz and $70 \mathrm{~km} \mathrm{SW}$ of Kerman, Iran. Coll. 1964 and " subm. by J. R. Caldwell, who assigned six levels to the mound. Level "O" represents pre-mound occupation, with examples of earliest known ceramics of the region, a coarse and poorly-fired straw-tempered ware called Lahlezar Coarse. Levels 1 and 2 represent the Iblis period, with some resemblance in ceramic decoration to Sialk III and Hissar I, and evidence of copper melting or smelting. Level 3 permits no cultural assignment. Levels 4 and 5 are assigned to Ali Abad period, with larger and more carelessly drawn designs than those of Levels 1 and 2 (Stein, 1927; Caldwell, mss.).

P.924. $\quad 5706 \pm 70$

(C), pre-mound occupation 3756 в.c. treatment.

P.925. Level 1, Iblish period

$5865 \pm 72$

Charred seeds and small bits of charcoal. 3915 B.C.

P-926. Level 2, Iblish period $5857 \pm 73$

Charcoal. 3907 B.C.

\section{P.927. Level 3}

$5574 \pm 58$

Charcoal and clay.

\section{P-928. Level 4, Ali Abad period}

3624 B.c.

Charcoal and clay.

$$
5432 \pm 57
$$

3482 B.c.

\section{P-929. Level 5, Ali Abad period}

Charcoal and ash.

$$
4678 \pm 55
$$

2728 B.c.

\section{Susa series, Iran}

Susa $\left(32^{\circ} 12^{\prime} \mathrm{N}\right.$ Lat, $48^{\circ} 20^{\prime} \mathrm{E}$ Long) lies near modern town of Shush, between Karkheh River and Karin River, ca. $40 \mathrm{mi}$ W of Shushtar, and $20 \mathrm{mi} \mathrm{SW}$ of Dezful, in Khuzistan, Iran. This citadel mound has been the subject of intermittent investigations and excavations since the mid-1800's, and contains levels dating from Neolithic to nearly modern times (McCown, 1955; LeBreton, 1957). Coll. 1963 by A. Ghirshman; subm. by P. Delougaz, Oriental Insti., Univ. of Chicago. 


\section{P.912. Locus 6, Apadana}

Charcoal and ash.

\section{P.913. Locus 50, Level A/III houses}

Ash. Comment: sample undersized.

\section{Gordion series, Turkey}

\section{B. Turkey}

Gordion ( $39^{\circ} 45^{\prime} \mathrm{N}$ Lat, $31^{\circ} 55^{\prime} \mathrm{E}$ Long), on the Sangarius River, $70 \mathrm{mi} \mathrm{SW}$ of Ankara, Turkey, is site of a Phrygian kingdon which fell during Cimmerian invasion of early 7 th century B.c. The City Mound (the town), rebuilt during period of Persian Empire, contains strata dating from Chalcolithic to Galatian periods, while burials in earth tumuli thus far excavated date from 740 B.c. through Hellenistic times. Excavations of the site by Univ. Mus., Univ. of Pennsylvania, have continued since 1950 under direction of R. S. Young. Subm. by E. Kohler (Kohler and Ralph, 1961; Pennsylvania III, V, VIII).

P-898. City Mound, Megaron 3, Room 3, seeds

$$
\mathbf{2 7 0 7} \pm \mathbf{5 2}
$$

Charred seeds found in pot in burnt fill by $\mathrm{S}$ wall, Room 3 in Megaron 3, City Mound. Coll. 1959. Comment: $\mathrm{NaOH}$ pretreatment.

\section{P-899. City Mound, Megaron 3, Room 3, textile 670 B.c.}

Charred textile fragments from burnt fill in $\mathrm{E}$ end of Room 3 in Megaron 3, City Mound. Coll. 1959. Comment: $\mathrm{NaOH}$ pretreatment.

P-901. City Mound, Terrace B

$$
\begin{gathered}
2693 \pm 54 \\
743 \text { B.C. }
\end{gathered}
$$

Charred reeds from roof, found burnt and smashed on floor of Room S-1, Terrace B, City Mound. Coll. 1961. Comment: $\mathrm{NaOH}$ pretreatment.

\section{P-902. Kücük Hüyük, Unit 2}

$2522 \pm 53$

Burnt wood from short logs sunk under floor as support for vertical beam, a structural member in original mud brick wall of Unit 2, Kücük Hüyük, Gordion. Coll. 1963. Comment: $\mathrm{NaOH}$ pretreatment. Estimated age: ca. 550 в.c.

\section{Karataş series, Turkey}

Karatas ( $36^{\circ} 45^{\prime} \mathrm{N}$ Lat, $30^{\circ} \mathrm{E}$ Long), is a small Early Bronze Age site $8 \mathrm{mi} \stackrel{3}{\mathrm{E}}$ of Elmali on upland Plain of Elmali in the interior of ancient Lycia, Antalya, Turkey, Excavations were conducted by M. J. Mellink, Bryn Mawr College, Bryn Mawr, Pennsylvania, in 1963 and 
1964. The mound is 3 to $4 \mathrm{~m}$ high, $100 \mathrm{~m}$ diam, and lies NE of a large necropolis. Coll. 1964 and subm. by Mellink (Mellink, 1964).

\section{P.920. Karataş, E.B.II, Pit 6}

Charcoal from Pit 6 in floor of burnt house.

\section{P.923. Karataş, E.B.II, courtyard} house.

Charcoal from fill under burnt floor in courtyard, E side, burn
$4274 \pm 62$ 2324 B.c.

$4228 \pm 62$ 2278 B.C.

P.917. Karataş, E.B.II, post hole

Charcoal from post hole N2, burnt building.

P.921. Karataş, E.B.II, Pit 5

Charcoal from Pit 5 in floor of burnt house.

\section{P.918. Karataş, E.B.II, floor}

Charcoal from floor level of burnt house, area $S$ of bins.

\section{P.919. Karataş, E.B.II, beam}

$4126 \pm 60$

Charcoal from beam (juniper?) found on floor near spur wall.

General Comment: all samples received $\mathrm{NaOH}$ pretreatment. Average age of six samples is $2236 \pm 25$ в.C. (or $2362 \pm 26$ в.C., 5730 half-life). Estimated age: 2500 to 2400 в.c. (M.J.M.) : The conflagration level on the main building at Karatas can be dated archaeologically to a late phase of Troy I period, or to end of Cilician Early Bronze II. Samples submitted came from same burnt level which was destroyed in one single catastrophe. There are two construction phases in the building from which samples were taken, but the interval between these phases was probably very brief-not more than one or two decades.

\section{ARCHAEOLOGIC SAMPLES: MEDITERRANEAN}

\section{Shipwreck series, Mediterranean Sea}

Samples in this series derive from sunken ships found at various places in the Mediterranean Sea, and explored and excavated by Peter Throckmorton, Univ. Mus., Univ. of Pennsylvania. Subm. by Throckmorton. Wood identifications made by Forest Products Lab., U. S. Dept. of Agriculture, Madison, Wisconsin.

\section{Plainer wreck}

The Planier wreck $\left(43^{\circ} 27^{\prime} \mathrm{N}\right.$ Lat, $5^{\circ} 17^{\prime} \mathrm{E}$ Long), off $\mathrm{S}$ coast of France near Marseilles, is a Roman ship believed to date to 1st century B.C. (Benoit, 1962). Coll. 1962. 


\section{P-848. Planier wreck, keel, No. 1} Sample pretreatment included additional boiling in $\mathrm{H}_{2} \mathrm{O}$ and pre-charring in nitrogen atmosphere.

\section{P-853. Planier wreck, keel, No. 2}

Wood from keel. Comment: sample pretreatment included additional boiling in $\mathrm{H}_{2} \mathrm{O}$ and pre-charring in nitrogen atmosphere.

\section{Albenga wreck}

The Albenga wreck ( $43^{\circ} 57^{\prime} \mathrm{N}$ Lat, $7^{\circ} 57^{\prime} \mathrm{E}$ Long), was found off the Riviera coast of northern Italy. Cargo of amphorae dated archaeologically to 1st quarter of 1st century. B.C.

\section{P.849. Albenga wreck}

$2192 \pm 52$

Scraps of pine planks and oak tenons. Comment: sample pretreatment included additional boiling in $\mathrm{H}_{2} \mathrm{O}$.

\section{Sparghi wreck}

The Sparghi wreck $\left(41^{\circ} 18^{\prime} \mathrm{N}\right.$ Lat, $9^{\circ} 27^{\prime} \mathrm{E}$ Long), found off coast of N. Sardinia, is a Roman ship believed to date to end of 2 nd century B.C. (120 to 100 B.C.). Coll 1957 (Lamboglia, 1958).

\section{P-850. Sparghi wreck, frame, No. 1}

$2254 \pm 52$

Wood, probably oak, from frame. Comment: sample pretreatment included pre-charring in nitrogen atmosphere.

\section{P-851. Sparghi wreck, frame, No. 2}

$$
2265 \pm 53
$$

Wood from frame. Comment: sample pretreatment included precharring in nitrogen atmosphere.

\section{Grand Congloue wreck}

The Grand Congloue wreck (43 $15^{\prime} \mathrm{N}$ Lat, $5^{\circ} 20^{\prime} \mathrm{E}$ Long), was found off coast near Marseilles, France. Raised in 1952, wreck is believed to date between 220 and 130 в.C., and may have been ship of Maarko Sestios (Benoit, 1961). Other materials from this wreck have been dated as A-66, $2295 \pm 110$ (Arizona I, solid carbon), and A-66-bis, $2160 \pm 150$ (Arizona III, carbon dioxide).

\section{Scrap of wooden planking. Comment: sample pretreatment incluced} only standard $3 \mathrm{~N} \mathrm{HCl}$; very difficult to purify. 
P-847. Grand Congloue wreck, planking, No. 2

119 B.c.

Scrap of wooden planking. Comment: sample stored in fresh water for $2 \mathrm{yr}$ after wreck was raised. Sample pretreatment included additional boiling in $\mathrm{H}_{2} \mathrm{O}$ and pre-charring in nitrogen atmosphere.

\section{P-852. Grand Congloue wreck, planking, No. 3}

$2036 \pm 51$

Miscellaneous scraps of planking. Comment: sample pretreatment included additional $\mathrm{NaOH}$; difficulty to purify.

\section{P-854. Grand Congloue wreck, frame or rib}

$1995 \pm 38$

Fragments of wooden frame or rib. Comment: sample stored in fresh water after raised. $\mathrm{NaOH}$ pretreatment; difficult to purify.

\section{Antikythera wreck}

The Antikythera wreck ( $35^{\circ} 55^{\prime} \mathrm{N}$ Lat, $23^{\circ} 22^{\prime} \mathrm{E} \mathrm{Long}$ ), was found off coast of Antikythera at W end of Sea of Crete, and is believed to have been sunk between 90 and 70 в.c. Coll. 1901 by persons unknown (Weinberg, et al., 1965).

\section{P-846. Antikythera wreck, planking}

Pieces of planking (Ulmus sp.), presumed to have been found lying on or just under surface of botom ment included only $3 \mathrm{~N} \mathrm{HCl}$; very difficult to purify.

San Pietro wreck

The San Pietro wreck ( $40^{\circ} 17^{\prime} \mathrm{N}$ Lat, $17^{\circ} 48^{\prime} \mathrm{E}$ Long), was found near Taranto, Italy. Cargo of sarcophagi were dated archaeologically to ca. A.D. 250, but it is believed that portions of a modern wreck may be involved here as well. Coll. 1965 (Throckmorton, mss.).

\section{P-877. San Pietro wreck, frame}

$158 \pm 36$

Fragment of wooden frame (Ulmus sp.) tightly wedged under Sarcophagi 18 and 19 at $S$ end of wreck at sea bottom level. Comment: sample pretreatment included only standard $3 \mathrm{~N} \mathrm{HCl}$ pretreatment. Date apparently confirms suspicion of modern wreck at same site.

\section{ARCHAEOLOGIC SAMPLES: EASTERN CANADA}

\section{A. Nova Scotia}

\section{Debert series, Nova Scotia}

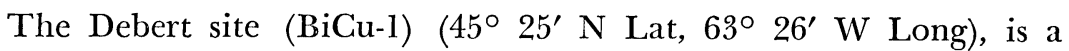
Paleo-Indian occupation site ca. $10 \mathrm{mi} \mathrm{W}$ of Truro, Nova Scotia, ca. 3 $\mathrm{mi} \mathrm{N}$ of shore of Minas Basin. Formal excavations were conducted in 1963 and 1964 under direction of D. S. Byers, R. S. Peabody Found., 
Andover, Massachusetts (Borns, 1965a, b; Byers, 1965; MacDonald, 1965; Stuckenrath, 1964, 1965). Wood identifications were made by Forest Products Lab., U. S. Dept. of Agriculture, Madison, Wisconsin.

\section{P.744. Feature 1}

$5019 \pm 70$

Charcoal (Picea sp.) from charred root or resin cinder, not associated with artifacts. Coll. 1963 by R. Stuckenrath.

\section{P.740. Feature 3}

$7671 \pm 92$

Charcoal (Picea sp.) from hearth in Feature 3, associated with Paleo-Indian artifacts. Coll. 1963 by R. Stuckenrath. Comment: $\mathrm{NaOH}$ pretreatment. Date is nearly 3000 yr younger than all other archaeologically-oriented samples from this site, and sample is presumed to include more modern materials.

\section{P-743. Feature 4}

$10,452 \pm 128$ 8502 B.C.

Charcoal (Picea sp.) from hearth in Feature 4, associated with Paleo-Indian artifacts. Coll. 1963 by J. MacDonald. Comment: $\mathrm{NaOH}$ pretreatment.

\section{P.739. Feature 7, Pit A}

$10,642 \pm 134$

Charcoal from Pit A in Feature 7, associated with Paleo-Indian artifacts. Coll. 1963 by J. MacDonald.

P.741. Feature 7, Pits A, B, C, and D

$10,531 \pm 126$ 8581 B.C.

Charcoal from Pits A, B, C, and D in Feature 7, associated with Paleo-Indian artifacts. Coll. 1963 by B. Powers. Comment: NaOH pretreatment.

\section{P-966. Feature 7, No. 3}

$10,557 \pm 121$ 8607 B.C.

Charcoal from hearth in Feature 7 , associated with Paleo-Indian artifacts. Coll. 1964 by D. Hakas.

\section{P-967. Feature 7, No. 4}

$10,626 \pm 244$

Charcoal from hearth in Feature 7 , associated with Paleo-Indian artifacts. Coll. 1964 by D. Hakas. Comment: sample undersized, diluted with "dead" $\mathrm{CO}_{2}$ from anthracite coal.

\section{P.970. Feature 11, hearth No. 1}

$10,477 \pm 90$ 8527 B.c.

Charcoal from Feature 11, hearth No. 1, associated with PaleoIndian artifacts. Coll. 1964 by R. Inglis and R. Stuckenrath. Comment: half of sample received standard 3N HCl pretreatment (P-970, 10,503 \pm 120), while other half received additional $\mathrm{NaOH}$ pretreatment (P-970A, $10,452 \pm 118)$, difference was not significant, and average is quoted here. 
P-971. Feature 11, hearth No. 2

$10,758 \pm 226$

8808 B.c.

Charcoal from Feature 11, hearth No. 2, associated with PaleoIndian artifacts. Coll. 1964 by R. Inglis and R. Stuckenrath. Comment: sample undersized, diluted with "dead" $\mathrm{CO}_{2}$ from anthracite coal.

\section{P.972. Feature 12}

$10,496 \pm 120$

Charcoal from hearth in Feature 12, associated with Paleo-Indian artifacts. Coll. 1964 by B. Rogers.

\section{P.973. Feature 15}

$10,637 \pm 114$

Charcoal from hearth in Feature 15, associated with Paleo-Indian artifacts. Coll. 1964 by M. Shaw et al.

\section{P.974. Feature 16}

$10,824 \pm 119$

Charcoal from hearth in Feature 16, associated with Paleo-Indian artifacts. Coll. 1964 by D. Fitts. Comment: $\mathrm{NaOH}$ pretreatment.

\section{P.975. Feature 17}

$11,011 \pm 225$

9061 в.C.

Charcoal from hearth in Feature 17, associated with Paleo-Indian artifacts. Coll. 1964 by D. Maclean. Comment: $\mathrm{NaOH}$ pretreatment. Sample undersized, diluted with "dead" $\mathrm{CO}_{2}$ from anthracite coal.

\section{P.977. Feature 19}

$10,113 \pm 275$

8163 B.C.

Charcoal from hearth in Feature 19, associated with Paleo-Indian artifacts. Coll. 1964 by S. Maclean. Comment: sample undersized, diluted with "dead" $\mathrm{CO}_{2}$ from anthracite coal.

\section{P.978. Section G root}

$5790 \pm 132$

3840 B.c.

Charred root, not associated with artifacts, from Section G. Coll. 1964 by R. Powers. Comment: sample undersized, diluted with "dead" $\mathrm{CO}_{2}$ from anthracite coal.

\section{P-859. Shoreline peat bog, 6 ft}

Peat, lowest 2 in. of core from $6 \mathrm{ft}$ bog (N $45^{\circ} 23^{\prime} \mathrm{N}$ Lat, $66^{\circ} 33^{\prime} \mathrm{W}$ Long), SW of Debert site along $\mathrm{N}$ shore of Minas Basin, $6 \mathrm{ft}$ above storm high tide. Bog surface roughly circular, $120 \mathrm{ft}$ diam. Comment: sample believed contaminated by drainage from local barnyard.

\section{P-867. Glenholme peat bog, $19 \mathrm{ft}$}

Peat, lowest 2 in. of core from $19 \mathrm{ft}$ bog $\left(63^{\circ} 32^{\prime} \mathrm{N}\right.$ Lat, $45^{\circ} 23^{\prime} \mathrm{W}$ Long), SW of Debert site, near Glenholme, Nova Scotia. Bog located in kettle hole in glacial outwash. 
P-951. Folley Lake peat bog, 26 ft

$10,664 \pm 101$

8714 B.C.

Peat, lowest $3 \mathrm{in}$. of core from $26 \mathrm{ft}$ bog $\left(45^{\circ} 33^{\prime} \mathrm{N} \mathrm{Lat}, 63^{\circ} 33^{\prime} \mathrm{W}\right.$ Long), NW of Debert site in kame-and-kettle complex bordering $\mathrm{N}$ end of Folley Lake, Colchester County, Nova Scotia. Bog fills lower $26 \mathrm{ft}$ of $75 \mathrm{ft}$ deep kettle. Comment: $\mathrm{NaOH}$ pretreatment.

\section{B. Newfoundland}

\section{Port aux Choix-2 series, Newfoundland}

Port aux Choix-2 $\left(50^{\circ} 43^{\prime} \mathrm{N}\right.$ Lat, $57^{\circ} 24^{\prime} \mathrm{W}$ Long), is a spring-summer seal-hunting site of middle Dorset culture located on outer shore of Cape Riche, Newfoundland, facing $\mathrm{N}$ to Strait of Belle Isle. Site lies on a 3 acre meadow crossed by minor beach lines prominent at $15 \mathrm{ft}$ and $25 \mathrm{ft}$ above present sealevel. Coll. during excavations directed by Elmer Harp, Jr., Dartmouth College Mus., Hanover, New Hampshire. Subm. by Harp (Harp, 1951; Stuckenrath and Anderson, 1966).

\section{P-682. House 2, charred fat}

$1859 \pm 50$

Charred fat and sand from primary occupation layer in central area of House 2, a dark soil stratum 4 in. below present surface, in association with fragments of steatite cooking pot bearing traces of same charred material. Coll. 1961. Comment: $\mathrm{NaOH}$ pretreatment.

P-683. House 2, charcoal

$1593 \pm 49$

Charcoal from primary occupation layer in SW quadrant of House 2, a dark soil stratum covered by layer of stones. Coll. 1961.

P.692. House 2, charcoal, midden top

$1736 \pm 48$

Charcoal from uppermost stratum of House 2 midden, 8 in. below present surface. Coll. 1962.

\section{P-693. House 2, charcoal, midden bottom}

$1659 \pm 48$

Charcoal from lowermost stratum of House 2 midden, 15 in. below present surface. Coll. 1962.

\section{P-727. House 4, charcoal}

$\mathbf{1 5 8 0} \pm \mathbf{5 4}$ A.D. 370

Charcoal from primary occupation layer in House 4, a black-soil stratum 4 in. below present surface, and covered by layer of stones. Coll. 1963.

P.676. House 5, charcoal

$1502 \pm 49$

Charcoal from primary occupation layer in House 5 , a dark soil stratum 6 in. below present surface. Coll. 1961. 
P-678A. House 6, charred fat, primary layer

Charred fat and sand from primary occupation layer in central area of House 6 , a dark soil stratum 6 in. below present surface, associated with steatite cooking pot. Comment: half of sample (P-678, $1734 \pm 49)$ received standard $3 \mathrm{~N} \mathrm{HCl}$ pretreatment, while other half received additional $\mathrm{NaOH}$ pretreatment $(\mathrm{P}-678 \mathrm{~A}, 1986 \pm 51)$; difference in ages (252 $\pm 71 \mathrm{yr}=3.5 \mathrm{sigma})$ is significant, and age of $\mathrm{P}-678 \mathrm{~A}$ is quoted here.

P.679. House 6, charcoal, secondary

$$
1623 \pm 47
$$

Charcoal from secondary occupation layer in SW quadrant of House 6, a mixed sand stratum 24 in. below present surface. Coll. 1961.

P-694. House 10, charcoal, 10 to 15 in.

$1602 \pm 49$

Charcoal from base of black soil stratum in depression within House 10, 10 to 15 in. below present surface. Coll. 1962.

P-695. House 10, charcoal, 8.5 in.

$1712 \pm 40$

Charcoal from base of black soil stratum in House 10, 8.5 in. below present surface. Coll. 1962.

\section{P-696. House 11, charcoal}

$1509 \pm 47$

Charcoal from base of black soil stratum in House 11,4 to 5 in. below present surface. Coll. 1962.

\section{P.729. House 12, charred wood}

$1538 \pm 55$

A.D. 412

Charred wood fragments, believed associated with infant burial in House 12, 10 in. below present surface. Coll. 1963. Comment: $\mathrm{NaOH}$ pretreatment.

\section{P.730. House 12, charred fat}

$1886 \pm 46$

Charred fat and sand from 3 in. below surface of central fire pit in House 12, associated with two human burials. Comment: $\mathrm{NaOH}$ pretreatment.

P.731. House 13, charred fat

$1891 \pm 56$

Charred fat and sand from front sector of House 13, 8 in. below present surface. Coll. 1963. Comment: $\mathrm{NaOH}$ pretreatment.

\section{P.732. House 15, charred fat}

$$
2294 \pm 51
$$

344 B.c.

Charred fat and sand from point near firebox of House 15, 8 in. below present surface. Coll. 1963. Comment: $\mathrm{NaOH}$ pretreatment. 
P-733. House 16, charcoal, midden

$1565 \pm 53$

Charcoal from midden deposit of House 16, 10 in. below present surface. Coll. 1963. Comment: $\mathrm{NaOH}$ pretreatment.

P.734. House 17, charcoal

$1465 \pm 51$

Charcoal from beside central firepit in House 17, 6 in. below present surface. Coll. 1963. Comment: $\mathrm{NaOH}$ pretreatment.

\section{P.735. House 17, charred fat}

$1817 \pm 51$

Charred fat and sand found next to small fire pit in House 17, 12 in. below present surface. Coll. 1963.

\section{P.736. House 18, charcoal}

$1683 \pm 49$

Charcoal from House 18, 6 in. below present surface. Coll. 1963.

\section{P.737. House 20, charcoal}

$1321 \pm 49$

Charcoal found on sterile sand in House 20, 6 in. below present surface. Coll. 1963.

General Comment: reader will note a discrepancy in dates corresponding to sample materials dated: charcoal samples average A.D. $370 \pm 13$, while charred fat samples average $6 \pm 21$ в.c. The difference $(376 \pm 34$ $\mathrm{yr}=11.1$ sigma) is certainly significant, but the reason therefore is not so obvious since all samples are believed to represent one general occupational phase.

\section{Labrador and Quebec}

\section{Strait of Belle Isle series, Labrador and Quebec}

This series of samples is from Strait of Belle Isle, along $S$ coast of Labrador and Quebec. Samples were collected from Boreal Archaic sites excavated in 1961 under direction of Elmer Harp, Jr., Dartmouth College Mus., Hanover, New Hampshire (1951). Arranged below by site, these samples provide the first prehistoric dates from this region.

\section{a. Forteau Bay-1}

Forteau Bay-1 (51 $29^{\prime} \mathrm{N}$ Lat, $56^{\circ} 58^{\prime} \mathrm{W}$ Long), is a Boreal Archaic site in the shore dunes just $\mathrm{W}$ of the settlement on tip of Buckle Point, Labrador. Coll. 1961.

\section{P-691. Forteau Bay-1}

Charcoal and sand from a buried turf layer exposed in a blowout in highest dunes of the site, and associated with artifacts. 


\section{b. Forteau Bay-3}

Forteau Bay-3 (51 $29^{\prime} \mathrm{N}$ Lat, $56^{\circ} 53^{\prime} \mathrm{W}$ Long), is a Boreal Archaic site on L'Anse aux Morts about $0.25 \mathrm{mi} \mathrm{N}$ of the present beach line, Labrador. Coll. 1961.

P-687. Forteau Bay-3, 20 to 40 in.

$6086 \pm 73$

Charcoal and sand from buried soil horizon, 20 to 40 in. below present surface in large central blowout lying between two brooks. Comment: $\mathrm{NaOH}$ pretreatment.

P-688. Forteau Bay-3, 40 in.

$5993 \pm 74$

Charcoal from turf 1 in thick, buried 40 in below present surface, from a point midway along $\mathrm{W}$ wall of large central blowout lying between two brooks, and associated with flint chips. Comment: $\mathrm{NaOH}$ pretreatment.

\section{P-689. Forteau Bay-3, 40 ft beach terrace}

$1335 \pm 46$

Sandy peat from turf line buried 8 in. below present surface at $\mathrm{E}$ end of site on second beach terrace, $40 \mathrm{ft}$ above present sealevel, and associated with flint chips.

\section{c. Blanc Sablon-1}

Blanc Sablon-1 ( $51^{\circ} 26^{\prime}$ N Lat, $57^{\circ} 09^{\prime} \mathrm{W}$ Long), is a Boreal Archaic site on W bank of Blanc Sablon R ca. $1 \mathrm{mi} \mathrm{W}$ of Labrador border, Quebec. Coll. 1961.

P-690. Blanc Sablon-1, 9 in.

Charcoal and sand from horizon containing flint chips, buried 9 in. below present surface, ca. $80 \mathrm{ft} \mathrm{S}$ of road and $0.25 \mathrm{mi} \mathrm{W}$ of Blanc Sablon R.

P-684. Blanc Sablon-1, 21 in.

$$
1068 \pm 45
$$

Charcoal, peat, and soil from horizon containing flint chips, buried 21 in. below present surface, ca. $250 \mathrm{ft} \mathrm{S}$ of road on $\mathrm{W}$ bank of Blanc Sablon R. Comment: $\mathrm{NaOH}$ pretreatment.

\section{d. Blanc Sablon-4}

Blanc Sablon-4 $\left(51^{\circ} 26^{\prime} \mathrm{N}\right.$ Lat, $57^{\circ} 09^{\prime} \mathrm{W}$ Long), is a Boreal Archaic site ca. $600 \mathrm{ft} \mathrm{W}$ of Blanc Sablon R, and ca. $0.25 \mathrm{mi} \mathrm{N}$ of road, $1 \mathrm{mi} \mathrm{W}$ of Labrador border, Quebec. Coll. 1961.

\section{P-686. Blanc Sablon-4}

$$
1223 \pm 45
$$

\section{A.D. 727}

Sandy peat from soil horizon containing Boreal Archaic implements and flint chips, buried 18 in. below present surface. Comment: $\mathrm{NaOH}$ pretreatment. 


\section{Baffin Island series, Canada}

This series represents pre-Dorset and Dorset occupations at six sites on Baffin Island, N.W.T., excavated as a joint project of Natl. Mus. Canada, Michigan St. Univ., and Natl. Sci. Found., under direction of M. S. Maxwell, Michigan State Univ. Coll. 1962 and subm. by Maxwell. The sites are in two groups: Annawalk (P-708) and Killilugak (P-699) sites $\left(62^{\circ} 44^{\prime} \mathrm{N}\right.$ Lat, $69^{\circ} 41^{\prime} \mathrm{W}$ Long), are near Okalivialuk at the mouth of the fjord leading to Lake Harbour; Loon (P-710), Closure (P707), Tanfield (P-698), and Nanook (P-704, P-706) sites (62 39' N Lat, $69^{\circ} 39^{\prime} \mathrm{W}$ Long), are on Cape Tanfield on S coast of Baffin Island, $15 \mathrm{mi}$ SE of Lake Harbour (Collins, 1956, 1957; Maxwell, 1962; Meldgaard, 1960; Pennsylvania IV; Rainey and Ralph, 1959; Stuckenrath and Anderson, 1966; Taylor, 1959).

\section{P-708. Annawalk site, pre-Dorset}

Cinder-like material of charred animal (seal?) fat and sand from Annawalk (KeDr-1) site, $60 \mathrm{ft}$ above present sealevel. Comment: many small rootlets present. (M.S.M.) Pre-Dorset typology and elevation suggest date of 2000 to 900 B.c. Compares culturally with Igloolik materials associated with P-207, $3958 \pm 168$; P-208, $3650 \pm 123$; P-209, $3906 \pm 133$; and P-210, $2898 \pm 136$ (Pennsylvania IV).

\section{P-710. Loon site, pre-Dorset}

$3577 \pm 69$

\section{B.C.}

Cinder-like material of charred animal (seal?) fat and sand from upper limit of permafrost at Loon (KdDq-10) site, $50 \mathrm{ft}$ above present sealcrel. Comment (M.S.M.): pre-Dorset typology and elevation suggest date of 1200 to 1000 B.c. Compares culturally with Igloolik materials associated with P-209, $3906 \pm 133$; and P-210, $2898 \pm 136$ (Pennsylvania IV).

\section{P.707. Closure site, pre-Dorset}

$4067 \pm 73$

2117 B.c.

Cinder-like material of charred animal (seal?) fat and sand from upper permafrost in $\mathrm{W}$ trench of Closure (KdDq-11) site, $40 \mathrm{ft}$ above present sealevel. Comment: some small roots present. (M.S.M.) PreDorset typology and elevation suggest date of 1100 to 800 B.c.; date is apparently too old. Compares culturally with Igloolik materials associated with P-210, $2898 \pm 136$ (Pennsylvania IV).

\section{P-699. Killillugak site, early Dorset}

$3043 \pm 63$

Cinder-like material of charred animal (seal?) fat and sand from layer above permafrost at Killilugak site (KeDr-3). Comment: some small roots present. (M.S.M.) Typological assessment may be interpreted 
as early Dorset (pre-900 B.C.) or as very late Dorset (A.D. 800 to 900); date confirms the former.

\section{P-698. Tanfield site, early Dorset}

Cinder-like material of charred animal (seal?) fat and sand from heavily encrusted cooking rock below upper permafrost at Tanfield site (KdDq-7), $23 \mathrm{ft}$ above present sealevel. Comment: some small roots present. Half of sample received standard $3 \mathrm{~N} \mathrm{HCl}$ pretreatment, other half received additional $2 \% \mathrm{NaOH}$ pretreatment; difference in ages was not significant, and average is quoted here. (M.S.M.) Typology and elevation suggest date of 600 to 400 B.c. Expected to be slightly younger than Collins' T-1 site, and compares culturally with materials from that site: P-74, $2183 \pm 122$; P-75, $2632 \pm 128$; and with Igloolik materials associated with P-212, $2404 \pm$ 137; and P-213, $2910 \pm 129$ (Pennsylvania IV).

\section{P-704. Nanook site, middle Dorset, sod}

$1916 \pm 61$

Dried sod and grasses associated with animal skins and branches of possible sleeping platform from permafrost layer, between component Layers 1 and 2 at Nanook site (KdDq-9-2). Comment (M.S.M.) : expected date of 400 to 200 B.c. Compares culturally with materials from Collins' T-3 site, associated with P-77, $2191 \pm 120$ (Pennsylvania IV).

P.706. Nanook site, middle Dorset,

$1827=61$ willow twigs A.D. 123

Willow twigs associated with animal skins and dried sod and grasses of P-704, this series.

\section{ARCHAEOLOGIC SAMPLES: ALASKA AND KODIAK ISLAND}

\section{A. Alaska}

\section{P.611. Late Choris, Choris Peninsula}

$2190=51$

240 B.C.

Charcoal from Choris site $\left(66^{\circ} 16^{\prime} \mathrm{N}\right.$ Lat, $161^{\circ} 52^{\prime} \mathrm{W}$ Long), near end of Choris Peninsula, Kotzebue Sound, Alaska. Sample is from Area 3, two beaches forward of the Choris "house beach," and believed to be Late Choris culture. Coll. 1958 and subm. by J. L. Giddings, Haffenreffer Mus., Bristol, Rhode Island (Rainey and Ralph, 1959; Pennsylvania IV; Stuckenrath and Anderson, 1966).

\section{Cape Prince of Wales series, Alaska}

Agulaak and Kugzruk sites (65 $45^{\prime} \mathrm{N}$ Lat, $168^{\circ} 15^{\prime} \mathrm{W}$ Long), are located on Cape Prince of Wales, Alaska. Coll. 1959 and subm. by J. L. Giddings, Haffenreffer Mus., Bristol, Rhode Island, who considers the sites to be of Norton culture (Rainey and Ralph, 1959; Pennsylvania IV; Giddings, 1964; Stuckenrath and Anderson, 1966). 


\section{P-599A. Agulaak site, Norton hearth}

Charcoal from Norton hearth on third beach line, Agulaak site. Comment: $\mathrm{NaOH}$ pretreatment.

\section{P-629. Kugzruk, Norton post}

$2306 \pm 38$

Wood from post in pond, associated with Norton houses. Comment: sample very difficult to purify. Half of sample was given standard $3 \mathrm{~N}$ $\mathrm{HCl}$ pretreatment, while other half received additional $\mathrm{NaOH}$ pretreatment; difference in ages was not significant, and average is quoted here.

P-598. Kugzruk, Norton House 2, No. 1

$2566 \pm 53$

Charcoal and sand from Norton stratum in House 2.

P-592. Kugzruk, Norton House 2, No. 2

616 B.C.

2.

633 B.C.

below sod. Comment: glass container broken in shipment, contents mixed with cotton packing; solid lumps of sample removed and cleaned for dating, remainder discarded.

\section{Cape Krusenstern series, Alaska}

The samples listed here are from a beach-ridge site on shore of Cape Krusenstern ( $67^{\circ} 06^{\prime}$ to $08^{\prime} \mathrm{N}$ Lat, $163^{\circ} 46^{\prime} \mathrm{W}$ Long), Alaska. Coll. and subm. by J. L. Giddings (Stuckenrath and Anderson, 1966).

\section{P-613. Birnirk-Thule Burial 6}

$906 \pm 56$

Bits of skin and wood from floor of Birnirk-Thule burial No. 6 . Coll. 1960.

P-612. Ipiutak House 17

$1441 \pm 58$

Charcoal from fireplace of Ipiutak House 17. Coll. 1959.

P-597A. Ipiutak House 30, No. 1

$1499 \pm 57$

Charcoal from charred timber of burned Ipiutak House 30. Coll. 1960. Comment: $\mathrm{NaOH}$ pretreatment.

P-595A. Ipiutak House 30, No. 2

$1944 \pm 52$

Charcoal from burned Ipiutak House 30, ca. $1 \mathrm{~m}$ below sod covering. Coll 1960. Comment: $\mathrm{NaOH}$ pretreatment.

\section{P.596A. Ipiutak House 60}

$1730 \pm 61$

Wood and charcoal from hearth $1 \mathrm{~m}$ below sod covering of Ipiutak House 60. Coll. 1961. Comment: $\mathrm{NaOH}$ pretreatment. 


\section{Old Whaling culture series, Alaska}

Samples of this series are from a beach ridge site $\left(67^{\circ} 06^{\prime}\right.$ to $08^{\prime} \mathrm{N}$ Lat, $166^{\circ} 46^{\prime} \mathrm{W}$ Long), on Cape Krusenstern, Alaska, excavated in 1960 and 1961 by J. L. Giddings. The samples are believed to derive from one cultural period identified by Giddings as the Old Whaling culture (Stuckenrath and Anderson, 1966).

P-618. House 24, wood, No. 1

Wood from wall post of House 24, ca. $1 \mathrm{~m}$ below sod covering. Comment: wood in crumbling condition. Half of sample was given standard $3 \mathrm{~N} \mathrm{HCl}$ pretreatment, while other half received additional $\mathrm{NaOH}$ pretreatment; difference in ages was not significant, and average is quoted here.

P.404. House 24, wood, No. 2

$$
2829 \pm 63
$$

Wood from wall post of House 24 at floor level.

879 B.c.

\section{P.617. House 24, wood and charcoal}

$$
2989 \pm 50
$$

1039 B.C.

Wood and charcoal from hearth of House 24, ca. $1 \mathrm{~m}$ below sod covering. Comment: half of sample received usual $3 \mathrm{~N} \mathrm{HCl}$ pretreatment, while other half received additional $\mathrm{NaOH}$ pretreatment; difference in ages was not significant, and average is quoted here.

\section{P.400. House 24, charcoal, No. 1}

$3678 \pm 53$

1728 B.C.

Charcoal from hearth in House 24, ca. $1 \mathrm{~m}$ below sod covering.

P.403. House 23, wood, No. 1

$2850 \pm 63$

Wood from wall post of House 23.

900 B.c.

P.621. House 23, wood, No. 2

$2859 \pm 63$

llood from wall post of House, ca. $1 \mathrm{~m}$ below sod covering.

P-615A. House 23, wood, No. 3

$2907 \pm 55$

957 B.c.

Wood from wall post of House 23, ca. $1 \mathrm{~m}$ below sod covering. Comment: half of sample received usual 3N HCl pretreatment (P-615, $2765 \pm 63$ ), while other half received additional $\mathrm{NaOH}$ pretreatment $(\mathrm{P}-615 \mathrm{~A}, 2907 \pm 55)$; difference in ages is significant $(142 \pm 84 \mathrm{yr}=1.7$ sigma), and age of P-615A is quoted here.

\section{P.623A. House 23, wood and charcoal}

Charcoal and partly charred wood from top of hearth in House ca. $1 \mathrm{~m}$ below sod covering. Comment: $\mathrm{NaOH}$ pretreatment. 
P-624. House 23, charcoal, No. 1

$3571 \pm 66$

1621 B.C. ing.

Charcoal from top of hearth in House 23, ca. $1 \mathrm{~m}$ below sod cover-

P-401. House 23, charcoal, No. 2

$3630 \pm 53$

Charcoal from hearth in House 23.

P-405. House 22, charcoal, No. 1

$3583 \pm 65$

Charcoal from hearth in House 22.

P-626. House 22, charcoal, No. 2

$3647 \pm 53$

1697 B.c.

Charcoal from hearth in House 22, ca. $1 \mathrm{~m}$ below sod covering. Comment: half of sample was given usual $3 \mathrm{~N} \mathrm{HCl}$ pretreatment, while other half received additional $\mathrm{NaOH}$ pretreatment; difference in ages was not significant, and average is quoted here.

P-402. House 21, charcoal and wood

$3084 \pm 63$

Charcoal and wood from House 21.

1134 B.C.

P-627. House 20, wood

$\mathbf{2 7 7 5} \pm \mathbf{5 0}$

Wood from wall post of House 20, ca. $1 \mathrm{~m}$ below sod covering. Comment: half of sample was given usual $3 \mathrm{~N} \mathrm{HCl}$ pretreatment, while other half received additional $\mathrm{NaOH}$ pretreatment; difference in ages was not significant, and average is quoted here.

Wood and charol from hearth in Summer Lodge 4 immediately under sod covering.

\section{P-619. Summer Lodge 5, charcoal}

1074 B.c.

Charcoal from hearth in Summer Lodge 5, immediately under sod covering. Comment: half of sample was given usual $3 \mathrm{~N} \mathrm{HCl}$ pretreatment, while other half received additional $\mathrm{NaOH}$ pretreatment; difference in ages was not significant, and average is quoted here.

General Comment: wood samples of this series derive from wall posts, all slender (ca. $5 \mathrm{~cm}$ diam) saplings presumed to have been cut locally. Average age of wood samples $(2848 \pm 23)$ and tight clustering of those dates would support this hypothesis. Charcoal samples are all from hearths within the houses, with average age of $3625 \pm 24$. Even if hearth charcoal derive from driftwood collected on local beaches, studies of driftwood in this area indicate that driftwood time lags are seldom more than $200 \mathrm{yr}$ (Giddings, 1952), hardly enough to account for the difference between wood and charcoal averages of 700 to 800 yr. Age of the 
charcoal samples meets archaeological expectations, and we are unable to account for the sample material discrepancy.

\section{Kodiak Island series}

\section{B. Kodiak Island}

Samples of this series were collected at eight sites on Kodiak Island in an attempt to establish the cultural and chronologic sequence of that island. Coll. 1961 to 1964 in excavations by Univ. of Wisconsin; subm. by W. S. Laughlin, Univ. of Wisconsin (Clark, 1966).

\section{a. Sitkalidak Roadcut site, No. 438}

Sitkalidak Roadcut site $\left(57^{\circ} 06^{\prime} \mathrm{N}\right.$ Lat, $153^{\circ} 11^{\prime} \mathrm{W}$ Long) is located at Ocean Bay, Sitkalidak Island in the Kodiak Island group. Coll. 1963 by D. W. Clark.

\section{P-1034. Ocean Bay I, base}

$5503 \pm 78$

Charcol, diffusely spreat $\mathbf{3 5 5 3}$ B.C. to $150 \mathrm{~cm}$ below to $150 \mathrm{~cm}$ below ground surface. Associated with artifacts of Ocean Bay I phase, apparently the earliest known culture in the Kodiak group. Comment: $\mathrm{NaOH}$ pretreatment.

\section{P-1036. Ocean Bay II, middle}

$3929 \pm 65$

Ciharcoal from middle of low ground mound surface, with melow ground surface, with majority of artifacts occurring in lower half. Comment: $\mathrm{NaOH}$ pretreatment.

\section{B. Kiavak site, No. 419}

This Kiavak site, No. $419\left(57^{\circ} 01^{\prime} \mathrm{N}\right.$ Lat, $153^{\circ} 36^{\prime} \mathrm{W}$ Long), lies on Kiavak Bay, Kodiak Island. Coll. 1963 by D. W. Clark.

\section{P-1038. Pre-Old Kiavak Occupation C}

$$
4698 \pm 71
$$

Charcoal from $180 \mathrm{~cm}$ below ground surface in sandy matrix $35 \mathrm{~cm}$ below nominal base of Old Kiavak component, C. Believed to date occupation of the site before inception of continuous refuse accumulation attributed to Old Kiavak component. Comment: $\mathrm{NaOH}$ pretreatment.

\section{P-1039. Old Kiavak Component C, base}

$$
3263 \pm 61
$$

Charcoal from $70 \mathrm{~cm}$ below ground surface, at base of major artifact frequency. Comment: $\mathrm{NaOH}$ pretreatment.

\section{P-1041. Ceramic Component B, top}

$937 \pm 49$ site.

Charred material scraped from potsherds found in upper level of 


\section{c. Three Saints site, No. 401}

The Three Saints site, No. 401 ( $57^{\circ} 07^{\prime}$ N Lat, $153^{\circ} 29^{\prime}$ W Long), lies on Three Saints Bay on Kodiak Island. Three Saints component is believed to date to about same time as Kachemak Bay III in Alaska (see antler sample date, P-138, $1369 \pm 102$, Pennsylvania IV; Rainey and Ralph, 1959; Stuckenrath and Anderson, 1966). Coll. 1962 by D. W. Clark.

P-1042. Three Saints, base

$$
2028 \pm 55
$$

Charcoal from base of Three Saints component, $172 \mathrm{~cm}$ below ground surface, associated with shallow clay-lined basin and fire-box.

\section{P-1043. Three Saints, top}

$1119 \pm 49$

Charcoal from upper portion of Three Saints component, $75 \mathrm{~cm}$ below ground surface.

\section{d. Kiavak site, No. 418}

This Kiavak site, No. $418\left(57^{\circ} 01^{\prime} \mathrm{N}\right.$ Lat, $153^{\circ} 36^{\prime} \mathrm{W}$ Long), lies quite close to Kiavak site No. 419 on Kiavak Bay, Kodiak Island. This SW ceramic variant of the Koniag phase is expected to be of about same age as that from Rolling Bay site (P-1047, P-1048), and younger than ceramic component of Kiavak site 419 (P-1041). Coll. 1963 by D. W. Clark.

P-1044. SW Koniag phase, base, No. 1

Charcoal from base of site and SW Koniag phase, A.D. $1670,215 \mathrm{~cm}$ below ground surface. Comment: $\mathrm{NaOH}$ pretreatment.

P-1045. SW Koniag phase, base, No. 2 $391 \pm 48$

Charcoal from kitchen refuse layer at base of site and SW Koniag phase, 200 to $225 \mathrm{~cm}$ below ground surface. Comment: $\mathrm{NaOH}$ pretreatment.

\section{e. Rolling Bay site, No. 420}

The Rolling Bay site, No. 420 (57 $02^{\prime}$ N Lat, $153^{\circ} 19^{\prime}$ W Long), lies on Sitkalidak Island of Kodiak group, NE of Sitkalidak Roadcut site (P-1034, P-1036). Samples are expected to date elder portion of this ceramic site. Coll. by D. W. Clark.

\section{P-1047. SW Koniag phase, base, No. 1}

$$
393 \pm 40
$$

Charcoal from hearth near base of SW Koniag component, ca. 200 $\mathrm{cm}$ below ground surface, in lowest quarter of stratigraphic sequence. Coll. 1961. 
P-1048. SW Koniag phase, base, No. 2

Charcoal from same hearth as P-1947. Coll. 1963.

A.D. 1597

\section{f. Monashka Bay site}

The Monashka Bay site ( $57^{\circ} 50^{\prime} \mathrm{N}$ Lat, $152^{\circ} 22^{\prime} \mathrm{W}$ Long), is located on Monashka Bay, near town of Kodiak on Kodiak Island. Coll. 1961 by D. W. Clark.

P-1049. Monashka Bay, aceramic Koniag component

A.D. 1652

$$
298 \pm 44
$$

Charcoal from middle of $\mathrm{B}$ component of this site, an aceramic variant of the Koniag, 84 to $99 \mathrm{~cm}$ below datum, and 46 to $61 \mathrm{~cm}$ below base of the A.D. 1912 volcanic ash layer. Comment: $\mathrm{NaOH}$ pretreatment.

\section{g. Chirikof Island site, No. 9}

Chirikof site, No. $9\left(55^{\circ} 50^{\prime} \mathrm{N}\right.$ Lat, $156^{\circ} 44^{\prime} \mathrm{W}$ Long), is in SW Anchorage of Chirikof Island in the Kodiak Group. This is a singlecomponent site, probably occupied as a camp for a short period of time. Coll. 1963 by D. W. Clark.

\section{P-1050. Chrikof Island site, No. 9}

Charcoal from two points within this site: (a) 10 to $40 \mathrm{~cm}$ below ground surface within the cultural horizon; and (b) from an apparent structure pit in a thicker portion of the cultural horizon, 54 to $76 \mathrm{~cm}$ below ground surface. Comment: date is apparently equal to or older than Ocean Bay II (P-1036), but younger than Ocean Bay I (P-1034).

\section{h. Anton Larsen Bay site, No. 241}

The Anton Larsen Bay site, No. $241\left(55^{\circ} 52^{\prime} \mathrm{N}\right.$ Lat, $152^{\circ}$ $40^{\prime} \mathrm{W}$ Long), is near mouth of $\mathrm{W}$ entrance of Anton Larsen Bay on NE shore of Kodiak Island. Coll. 1964 by D. W. Clark.

\section{P-1057. Anton Larsen Bay site, No. 241}

$$
2033 \pm 52
$$
burnt and collapsed structure, 13 below datum. Comparative typology suggests that this material, the main component at this site, may be correlated with that from Three Saints Bay; date is equivalent of that for base of Three Saints component (P-1042).

$$
\text { V. ARCHAEOLOGIC SAMPLES: SOUTH AMERICA }
$$

$$
\text { A. Peru }
$$

\section{Rio Nazaratique series, Peru}

This series of samples derives from cluster of three sites $\left(10^{\circ} 30^{\prime} \mathrm{S}\right.$ Lat, $74^{\circ} 30^{\prime} \mathrm{W}$ Long), on the Rio Nazaratique, Dept. of Pasco, Peru. 
Coll. 1964 by W. A. Allen; subm. by D. W. Lathrap, Univ. of Illinois, Urbana.

\section{P.990. Site PAC-14, 4.5 to $5 \mathrm{ft}$}

$3368 \pm 100$

Charcoal from site PAC-14, 4.5 to $5 \mathrm{ft}$, associated with rough brown ware and poorly burnished ware, earliest ceramic material thus far encountered in the area. Comment: sample undersized and diluted with "dead" anthracite carbon dioxide.

\section{P-991. Site PAC-14, 4 to $4.5 \mathrm{ft}$}

$3728 \pm 100$

Charcoal from site PAC-14, 4 to $4.5 \mathrm{ft}$, associated with a fine sandtempered brown ware. Comment: sample undersized, diluted with "dead" anthracite carbon dioxide.

\section{P-992. Site PAC-14, 3.5 to $3.75 \mathrm{ft}$}

Charcoal from Site PAC-14, 3.5 to $3.75 \mathrm{ft}$, associated with rough plain sand-tempered ware. Comment: sample undersized and diluted with "dead" anthracite carbon dioxide.

P-993. Site PAC-14, 3.25 to $2.5 \mathrm{ft}$

$3225 \pm 68$ 1275 B.C.

Charcoal from Site PAC-14, 3.25 to $3.5 \mathrm{ft}$, associated with a crude sand-tempered ware.

\section{P-995. Site PAC-14, 1 to $1.5 \mathrm{ft}$}

$1346 \pm 100$

Charcoal from Site PAC-14, 1 to $1.5 \mathrm{ft}$, associated with ceramics similar to Late Tutishcainyo defined by Lathrap at Yarinacocha, Peru. Comment: sample undersized. and diluted with "dead" anthracite carbon dioxide. Compare Y-1546, $670 \pm 100$ B.C., from depth of 2.25 to 2.75 $\mathrm{ft}$, this site.

\section{P.996. Site PAC-12}

$$
1249 \pm 51
$$

Charcoal from Site PAC-12, associated with a presumed burial feature, and with thick ceramics displaying brushed and incised decoration.

\section{P-997. Site PAC-16, 1 to $1.25 \mathrm{ft}$}

$$
1426 \pm 100
$$

Charcoal from Site PAC-16, 1 to $1.25 \mathrm{ft}$, associated with ceramics displaying a fine-line incising within alternating triangles. Comment: sample undersized and diluted with "dead" anthracite carbon dioxide.

\section{B. Venezuela}

\section{P.953. EI Ranchon site, Venezuela}

$$
1086 \pm 45
$$

Charcoal from El Ranchon (M1) site $\left(9^{\circ} \mathrm{N}\right.$ Lat, $71^{\circ} \mathrm{W}$ Long), located on shore of Lake Maracaibo near Zancudo River, Venezuela, 
Sample comes from level of the Zancudo phase, Level 4, the first geologic stratum above lacustrine sediments, and antedates formation of tropical forest cover in this area. Soils analyses indicate a grass vegetation for this level. Coll. 1964 and subm. by Mario Sanoja O., Univ. de Los Andes, Mérida, Venezuela. Comment (M.S.O.): cultural traits link Zancudo phase with Valencia phase on north-central coast of Venezuela, and with late ceramic cultures in Colombian-Venezuelan highlands. Compare Y-630, $1000 \pm 70 ;$ Y-631, $980 \pm 110 ;$ and Y-632, $1000 \pm 100$ (Yale VI) from the La Mata site in Venezuela, where samples were associated with pottery of Valencia style.

VI. ARCHAEOLOGIC SAMPLES: CENTRAL AMERICA

\section{A. British Honduras}

\section{P-1028. Altun Ha, British Honduras \\ $1544 \pm 62$}

Carbonized material, perhaps copal, from lower portion of distinctive two-piece chimneyed incensario found in tomb excavated in small group of small mounds just $\mathrm{S}$ of center of Altun $\mathrm{Ha}$, a Maya site at Rockstone Pond $\left(17^{\circ} 45^{\prime} \mathrm{N}\right.$ Lat, $88^{\circ} 21^{\prime} \mathrm{W}$ Long), $30.5 \mathrm{mi} \mathrm{N}$ of Belize, 9 mi $\mathrm{W}$ of sea coast, British Honduras. Coll. 1964 by D. M. Pendergast, Field Director of Royal Ontario Mus. Project; subm. by A. D. Tushingham, R.O.M. Site is believed to have been occupied from late pre-Classic to terminal Classic times, and sample derives from earliest of three tombs found in Mound E-1 (Pendergast, 1965).

\section{Tikal series, Guatemala}

\section{B. Guatemala}

Tikal ( $17^{\circ} 13^{\prime} \mathrm{N}$ Lat, $89^{\circ} 39^{\prime} \mathrm{W}$ Long), in El Peten, Guatemala, is the site of extensive excavations and restorations of the Lowland Maya Pre-Classic to Post-Classic periods by the University Mus., Univ. of Pennsylvania, in collaboration with the government of Guatemala. The samples listed below were coll. from 1961 to 1964, and subm. by W. R. Coe, Director of the Tikal Project. The following discussion is presented by Coe in order to provide the necessary understanding of sample derivation and date significance in the archaeologically complex North Acropolis (Pennsylvania V).

The radiocarbon results reviewed here pertain to two series of samples submitted to the Radiocarbon Lab. of the Univ. of Pennsylvania by the writer (W.R.C.). The results of both are calculated on the basis of a 5568 half-life. The first series (P-535, P-560 through P-563, P-565 through P-567, and P-569 through P-575) were dated in 1962, and the second (P-768, P-750 through P-759) in 1964. All but one of these (P-759) derive from excavations of the North Acropolis at Tikal.

The long, extraordinarily complex architectural evolution of the North Acropolis has been outlined elsewhere (Coe, 1965a, b; Coe and 
McGinn, 1963). It consists essentially of a series of great superimposed platforms, each of which sustains various buildings of a ceremonial nature. The majority of radiocarbon samples considered here are charcoals recovered from the fills employed in construction. Such charcoals occur in fill as randomly as potsherds and other cultural material. The true source of this charcoal is difficult if not impossible to isolate. This is basically true of the actual fills. We assume that the cultural detritus and charcoal found in such fills ultimately derive from household middens, workshop scrap, and from other accumulations of trash resulting from daily living at Tikal. The fill matrix ranges from limestone rubble, to demolished prior constructions, marl scraped from bedrock, and earths and clays. A serious drawback in assessing sources is the extent to which the old was demolished to make way for the new at Tikal. This is partly evidenced by physical fits between cultural items separated by almost a millennium of constant building activity (Coe, 1965a, p. 1409). Old materials were obviously projected ahead in time at such constructionally dynamic sites as Tikal. When we estimate that a fill was laid down and a structure built, say, at A.D. 100, we ought not to be surprised that we receive a date centuries earlier for the charcoal recovered from the fill. The ceramicist faces the same problem of controlling redeposition as he evaluates the sherd material from constructional fill. The fact is that the sherds, charcoal and other collected contents of fill can and probably often do have countless disparate sources in time and space. They finally end up in a fill at a certain date, but here they are physically in association by pure chance. A great deal remains to be explored regarding differing degrees, if any, to which charcoal and sherds are susceptible to redeposition and anachronism. Often the ceramicist judges a sherd collection from a particular fill as homogenous and approximately contemporary in manufacture and breakage with the filling operation; yet charcoal from this same fill can give a radiocarbon date centuries too early.

The point is simply that the content of a fill matrix at Tikal cannot be assumed to express contemporary reality, ceramic, or otherwise. A pot must be broken, a hearth extinguished and cold before the products of both are available as constructional fill. This requires that we date a fill in terms of having been collected and laid down no earlier than the time of the latest material within it. In submitting charcoal to a laboratory for radiocarbon determination, we are aware of how limited our control of the sample is. Granted, we may well control a sample in terms of its sequential or stratigraphic provenience and we often know the nature of the pottery with which it is physically associated. However, there remain a number of clearcut, potentially significant variables that can color the radiocarbon results treated in this paper.

Post-sample error ("PSG"). As shown by Satterthwaite and Ralph (1960), this phrase indicates the growth-time interval between the "death" of the organic source of the sample and the "death" of the or- 
ganic matrix of the source (cf. also Coe and Stuckenrath, 1964, p. 18). The PSG time-span can be considerable between pith wood and cambium growth. Zapote wood. commonly used in construction at Tikal and prized as firewood today (and probably anciently as well), offers a case in which PSG can amount to a few centuries (cf. Ralph, 1965). The error becomes more difficult to estimate when a charcoal sample historically derives from multiple organic sources (see PH, below). Similarly, the greater the life-span of the sample's matrix (e.g., tree), the greater the potential is for significant PSG. While it is possible to have wood charcoals identified as to contributing genera, there appears to be little reliable data on differing life-spans of tropical trees. In an attempt to minimize significant PSG error, one might exclude the larger pieces of charcoal in a sample and submit only the smallest pieces in the hope that the latter derive from the youngest growth of the trees represented in the sample. While this is logical, it is hard to practice. In the case of soft-wood samples (thus, from trees relatively short-lived), it probably makes little difference whether trunk pith or lofty twigs are run. Moreover, twigs are difficult to recognize and often disintegrate with collection, bagging and transportation.

Placement history ("PH"). The total interval that may be termed the PH of the sample (Coe and Stuckenrath, 1964, p. 18) allows for the time between the death carbonization of the source and final archaeological placement. It is a gap that is either infinitesimal or huge; a gap of almost a millennium has been discovered between fitting monument fragments at Tikal, and cyclical trash reclamation and renewed building can affect radiocarbon results to at least an equal degree.

Average death-rate (" $\mathrm{X}$ "). If a charcoal sample is botanically inhomogeneous, the radiocarbon result is either an average of the deathdates of the original sources, or is based on a portion not necessarily representative of the total. A part of each Tikal sample is usually submitted to the U. S. Dept. of Agriculture, Forest Products Lab. for expert identification (for this we are indebted to B. Francis Kukachka and Robert C. Keoppen). Presumably, generic identification refers only to the preponderant genus, and the average death-date or " $\mathrm{X}$ " variable is potentially present.

Contamination. The occasions for contamination, aboriginal and present-day, are innumerable but probably for the most part identifiable. Knowing the porosity of limestone masonry at Tikal, one can see how later burnings could, with rains, infect stratigraphically earlier samples. Rootlets penetrate to surprising depths in Tikal architectural contexts. Contamination, nevertheless, is probably a minor source of error within the group of samples treated in this paper.

Sigma. There are two out of three chances that $\mathrm{X}$ (average deathdate) falls within the one-sigma date-spread yielded by the analysis of the sample (Coe and Stuckenrath, 1964, p. 18). The chances that the exact value lies outside the one-sigma date-spread are one in three, and one in 
twenty outside a two-sigma spread (Satterthwaite and Ralph, 1960, p. 168).

Others. As noted, a half-life value of 5568 is used to calculate the dates discussed in this paper. Were the results to be given in terms of the 5730 half-life, they would be older by some $240 \mathrm{yr}$.

Finally, there is the special matter of Maya-Christian calendrical correlation. The 600- or 700-yr-long Classic Period of the lowland Maya is replete with inscriptions in the Maya system, providing a Maya dating framework for construction, pottery, etc. Most lines of evidence, including radiocarbon tests on Maya-dated wood (Satterthwaite and Ralph, 1960; Ralph, 1965), indicate Correlation B to be the most likely. Correlation $\mathrm{A}$, the next most favored contender, places a Maya event about $260 \mathrm{yr}$ earlier in time than does Correlation B. It is assumed in the following that Correlation B is correct. However, when a phenomenon is expected to date A.D. 700 and we receive a date on "associated" charcoal of A.D. 450, we can rationalize the discrepancy by invoking PH, PSG, X, or Correlation A.

The samples discussed here are presented in accord with their estimated sources of deposition, with the exception of No. 2 which appears according to ceramic position. In Fig. 1, each radiocarbon result has been plotted in time, each with its one-sigma date-spread. The archaeological sources of the samples (except No. 2) are also shown in Fig. 1, a diagram of the pertinent portion of the North Acropolis sequence. This diagram is vertically oriented (by Correlation $\mathrm{B}$ ) to time and to the Tikal ceramic sequence. The symbol $\mathrm{X}$ is used to plot estimated dates of deposition of the samples, departures of circles from the line representing disagreement between what was anticipated and what radiocarbon analyses give us. Positions $\mathrm{X}$ are based upon what seems reasonable, knowing the stratigraphic order, the contemporaneity of certain samples, the ceramic sequence, and calculated dates and spans of architectural components. Impressed by the volume of construction in the North Acropolis, we originally were inclined to see a certain feature built, say, at 300 B.C. If the radiocarbon results point to 150 B.c., perhaps only a romantic tendency to over-estimate age makes us shy from the results.

\section{P.750. North Acropolis, Ref. No. 1}

$2538 \pm 53$ 588 в.c.

Tikal, North Acropolis, pit in bedrock containing trash and human remains. Excavated as 12P-Lot 151. Ceramic content is pure Eb. Charcoal, randomly scattered as small pieces in trash, is believed to have been deposited by an $\mathrm{Eb}$ domestic occupation of the North Acropolis area. The simple architecture of this occupation appears to have been totally dismantled for later construction. The charcoal was identified simply as hardwood. The result is consistent with current estimates of roughly

Fig. 1. Diagram of North Acropolis sequence, Tikal, related (by Correlation B and by $\mathrm{C}^{14}$ ages computed from the $5570-\mathrm{yr}$ half life) to the ceramic sequence. 
$\dot{i} \underset{i}{i}$

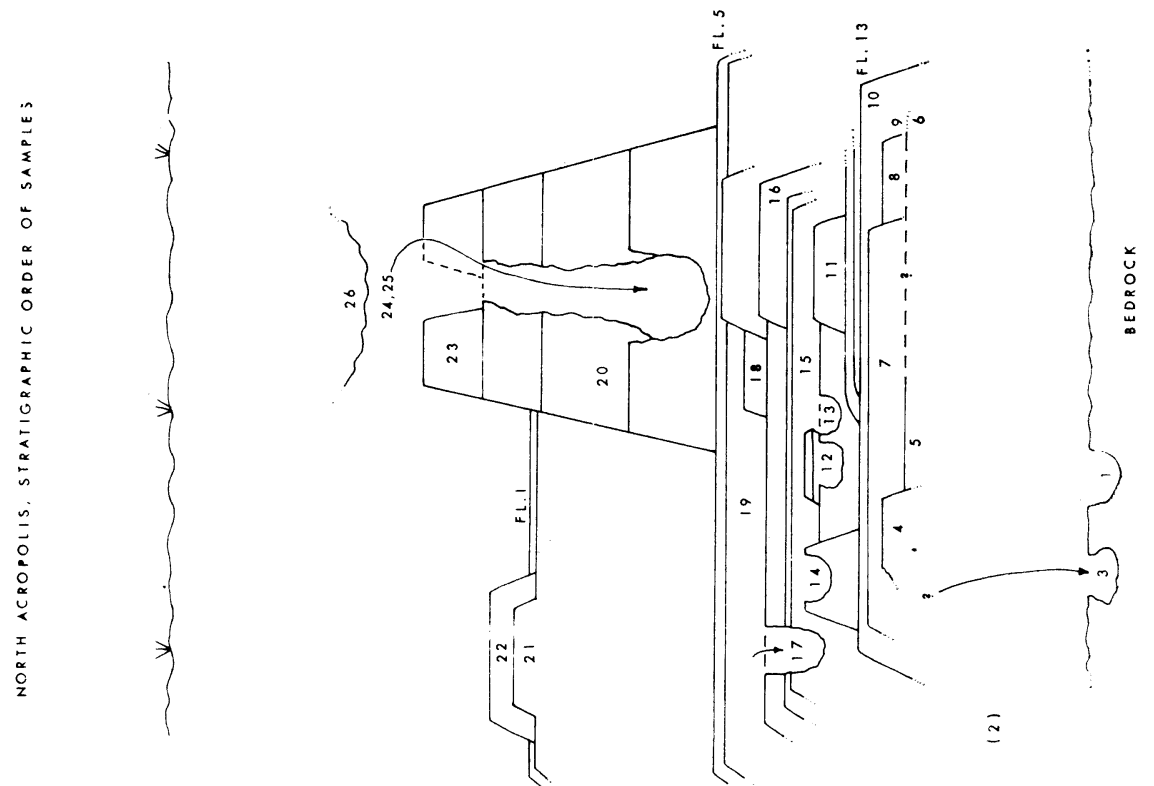

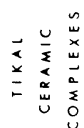

POSTCLASSIC | LaTECLASSIC |EARLYCLASSIC

PRECLASSIC

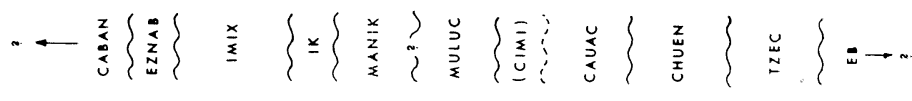

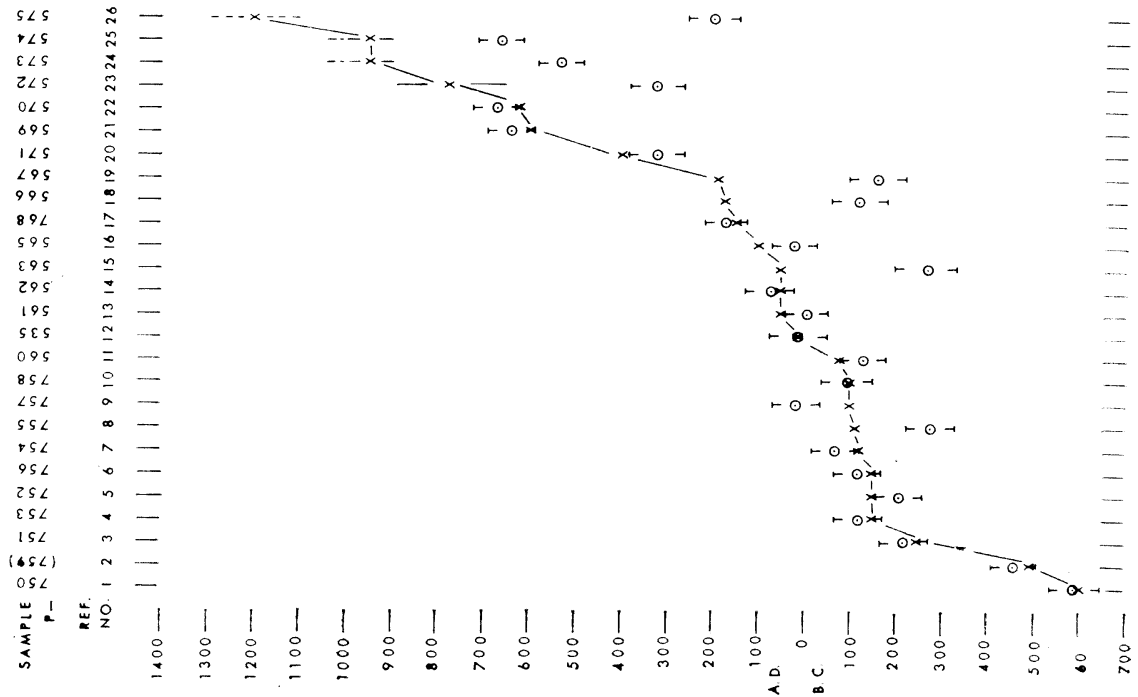


where $\mathrm{Eb}$ ceramics belong in a middle Preclassic framework. This one date helps us to place $\mathrm{Eb}$ material about or within the 6th century B.C.

P.759. 71F-Lot 57, Ref. No. 2

$2406 \pm 47$

456 B.C.

Tikal, midden buried beneath platform sustaining Structures 5F-17 and 18. Excavated as 71F-Lot 57. Charcoal is scattered in this midden, and the latter produces an excellent sample of Tzec ceramic complex material. Deposit underlies deposits of Chuen material by more than a meter. The uniqueness of this deposit and the smallness of the charcoal sample required that the whole sample be submitted for radiocarbon analysis. Thus, the nature of the charcoal is unknown. This sample was approx. $10 \%$ undersized. The known sequential position of Tzec (Mamom) pottery makes this date acceptable.

\section{P.751. North Acropolis, Ref. No. 3}

$2169 \pm 52$

Tikal, North Acropolis, Chultun 5D-6, ash-banded dark fill, deliberately placed. Excavated as 12P-Lot 164. Chultun probably but not certainly sealed by Str. 5D-Sub. 14-1st, -2nd, or -3rd but definitely sealed by Floor 15 platform. Associated large sherd sample is mixed but the latest material is of the Chuen complex. Charcoal, id. as hardwood, was abundant and occurred throughout the fill up to $2 \mathrm{~cm}$ in size. Keeping ceramic and stratigraphic data in mind, I would favor a date of ca. 250 B.c. for the filling and sealing of this Chultun. The oldest limit within 1-sigma of the result, 271 B.c., approximates this estimate.

\section{P.753. North Acropolis, Ref. No. 4}

$2068 \pm 52$

118 B.c.

Tikal, North Acropolis, fill of Str. 5D-Sub. 14-1st. Excavated as 12PLot 152. Charcoal scattered in fill, one interesting component of which is many lumps of painted, burned plaster from a prior construction (possibly from Str. 5D-Sub. 14-2nd). Chuen ceramics are latest in this fill. Three burials $(122,123,126)$ in this same fill have Chuen vessels with them. Charcoal identified as Manilkara (= Achras) zapote, a hardwood. A date of 150 в.c. for construction of this feature is not unreasonable. This estimate is within the 1-sigma date-spread of the result. However, PSG and PH are theoretically pertinent here.

\section{P.752. North Acropolis, Ref. No. 5}

$2157 \pm 52$

Tikal, North Acropolis, ballast of Floor 16 laid against Str. 5D-Sub. 14-1st during its use. Excavated as 12P-Lot 143. Chuen sherds are latest in this small lot. Small, randomly occurring pieces of charcoal, id. as Leguminosa (hardwood), entered the floor ballast at a later time than the deposition date of No. 4 . A date of ca. 150 B.c. is reasonable for the laying of Floor 16. It is practically allowable by the 1-sigma date-spread of the result, through the potential effects of PSG and PH must be kept in mind. 
$2064 \pm 52$

P.756. North Acropolis, Ref. No. 6

114 B.c.

Tikal, North Acropolis, packed earth level just $\mathrm{S}$ of Floor 15 platform and predating it. Excavated as 12P-Lot 116. This level is stratigraphically the equivalent of Floors $16-20$ to the $\mathrm{N}$ and may be the decomposed weathered remains of one or more of these floors. Charcoal identified as Manilkara (= Achras) zapote, a hardwood. An estimated age of 150 в.c. for this level is within the 1-sigma date-spread of the result. PSG and PH however could be effective. The Chuen sherds from this fill were of early types and markedly weathered, suggesting a significant ceramic PH.

\section{P.754. North Acropolis, Ref. No. 7}

$2017 \pm 52$

67 B.c.

Tikal, North Acropolis, fill of Floor 15 platform, the first major construction in the North Acropolis sequence. Excavated as 12P-Lot 138. Charcoal occurred randomly in fill and identified as Bursera, a hardwood. The ceramic content of this fill was Chuen with little earlier admixture. An estimated construction date of ca. 120 B.c. is within the 1-sigma date-spread of the result.

P-755. North Acropolis, Ref. No. 8

$2225 \pm 55$

275 B.c.

Tikal, North Acropolis, probable firepit sealed within fill of semicircular masonry addition against face of Floor 15 platform (cf. No. 7). Pit contained a scorched wall, ash, charcoal, and flint. Excavated as 12PLot 120. Construction during a time of Chuen production. Charcoal identified as unspecified hardwood. The result provides only a lower limit date for construction. PSG and PH are surely operable if we accept No. 7. Perhaps structural members from dismantled earlier construction were burned here.

\section{P.757. North Acropolis, Ref. No. 9}

$1930 \pm 51$

Tikal, North Acropolis, earth level overlying level producing No. 6; level is a $\mathrm{S}$ base of the Floor 15 platform and was accumulated after the construction of the semicircular addition to it (cf. No. 8). Charcoal was collected from the surface of this level; some ash was present, but no evidence of in situ burning. Excavated as 12P-Lot 114. Definitely sealed by Floor 13 platform built during a time of Chuen production. Charcoal identified as Bursera, a hardwood. This result must be compared with that of No. 10. It is extremely doubtful that Floor 13 platform was built as late as No. 9 would indicate. I would estimate 100 B.c. as a reasonable construction date. To achieve this, it is necessary to allow either for contamination or operate within a 3-sigma date-spread.

\section{P.758. North Acropolis, Ref. No. 10}

$2040 \pm 53$

90 в.c.

Tikal, North Acropolis, fill or Floor 13 platform (cf. No. 9). Charcoal was collected over a period of a month of excavation of this fill. Ex- 
cavated as $12 \mathrm{P}$-Lot 89 , which contains a very large amount of pure late Chuen complex material. Charcoal identified as simply hardwood. An estimated rough construction date of 100 B.c. for this platform is well within the 1-sigma limits of the result.

P-560. North Acropolis, Ref. No. 11

$2075 \pm 49$

125 B.C.

Tikal, North Acropolis, marl fill of Str. 5D-Sub. 3-5th, built upon the second of two grading floors laid on Floor 13 platform (cf. No. 10). Excavated as 12P-Lot 68 . The randomly occurring charcoal is identified as hardwood. The associated sherd material could be either late Chuen or early Cauac complex. This structure was built close in time to Burial 166 with its large number of Cauac vessels. A date of ca. 75 B.c. would be acceptable and this is within the 1-sigma date-spread of the radiocarbon result.

\section{P.535. North Acropolis, Ref. No. 12}

$1934 \pm 63$

Tikal, North Acropolis, Burial 85. This important Cauac complex burial is stratigraphically later than Burial 166 (cf. No. 11). Burned slivers of wood, id. as Pinus sp., were found in a bowl. Excavated as 12PLot 78. Since pine is relatively short-lived and the pieces of it appear to have been deliberately placed as burned pieces in the bowl, PSG and PH are probably minimal. We conclude that Burial 85 was made somewhere in time ca. A.D. 1. This is a primary reference point in the North Acropolis series of dates.

P.561. North Acropolis, Ref. No. 13

$1951 \pm 46$

1 B.c.

Tikal, North Acropolis, sealed deposit directly in front of and postdating the construction of Str. 5-D-Sub. 2-1st, the later of two platforms over and thus postdating Burial 85 (cf. N. 12). This deposit, excavated as 12P-Lot 74, lay within a pit and consisted of concentrated charcoal up to sizes suggesting the burned remains of a pole and thatch building on the platform designated as Sub. 2-1st (known to have carried such a building). The charcoal submitted for identification is hardwood, unspecified. If this is the immediate source of the charcoal, a date of A.D. 25 is considered a reasonable construction date for Sub. 2-1st. This lies within the 1-sigma range of the result. The presumed burning of the building might have taken place at ca. A.D. 50 (cf. No. 14). This estimate is also within the 1-sigma limits of the result.

\section{P-562. North Acropolis, Ref. No. 14}

$\mathbf{1 8 7 4} \pm \mathbf{5 4}$

Tikal, North Acropolis, unsealed pit in floor of $\mathrm{W}$ portion of front room of Str. 5D-Sub. 1-1st. Excavated as 12G-Lot 26. Charcoal occurred in this pit with signs of in situ burning. The situation suggests a terminal fire sacrifice in relation to the abandonment of this building and almost the entire contemporary stage of the North Acropolis (followed by a 
massive filling operation; cf. No. 15). Charcoal identified as hardwood. The act of burning probably contemporary with deposition of No. 13 . Abandonment of this stage of the Acropolis is best placed at ca. A.D. 60, an estimate that falls within the l-sigma limits of the $\mathrm{C}^{14}$ result.

\section{P-563. North Acropolis, Ref. No. 15}

Tikal, North Acropolis, fill, maximally $5 \mathrm{~m}$ thick, consisting of local demolition debris and especially deposited fill from elsewhere, the whole laid over a major stage of the North Acropolis, sealing Nos. 12, 13, and 14. Plentiful charcoal scattered randomly in this fill, up to thumb-nail size. Identified as hardwood. Excavated as 12P-Lot 55. The ceramic material of this fill was preponderantly Cauac, with nothing later. Admixture of earlier materials quantitatively slight. T. Patrick Culbert, Project ceramicist, believes that the fill derives in part from middens not much earlier than the fill in the North Acropolis. If so, the $\mathrm{C}^{14}$ result is ca. 250 yr too early. $\mathrm{PH}$, though conceivably a factor, does not seem to be significantly operable here in ceramics. This massive fill was laid down in blocks surrounded by fill-retaining walls, and charcoal may therefore be derived from relatively early middens.

\section{P-565. North Acropolis, Ref. No. 16}

$1926 \pm 48$

Tikal, North Acropolis, deposit of sherds, charcoal and ash sealed by front stairway of Str. 5D-26-4th and laying on demolished stairway of 26-5th; both structures were built on Floor 8. The deposit probably represents a terminal ceremony in connection with the abandonment of -5 th and the decision to built -4 th. Excavated as 12P-Lot 58. The charcoal is hardwood. The latest of the associated pottery is of the Protoclassic late facet (Cimi) of the Cauac complex. A construction date of ca. A.D. 100 for 26-4th seems proper and this is almost a quarter century younger than the youngest 1-sigma limit of the radiocarbon result. No. 16 presumably pertains to -5 th. Therefore, in relation to building -4 th, $\mathrm{PH}$ is operable and perhaps PSG as well.

P-768. North Acropolis, Ref. No. 17

$1777 \pm 45$

Tikal, North Acropolis, Burial 125 upper pit fill, cut through Floor 7 (laid during use of Str. 5D-26-4th; cf. No. 16) and through stairway base of Str. 5D-22-4th-B and sealed by -4th-A. Considerable lensed charcoal occurred in the burial pit upper fill along with charred structural plaster matching the charred stairway of 22-4th-B, suggesting that the charcoal derives from a burned perishable building of -B. The charcoal, id. as Manilkara (= Achras) zapote, might derive from wood cut as structural members for -B. A date of A.D. 150 is not unreasonable and is within the 1-sigma limits of the radiocarbon result. It pertains to a time of Cimi ceramic production. 


\section{P.566. North Acropolis, Ref. No. 18}

Tikal, North Acropolis, fill of str. 5D-26-3rd, built on Floor 7 (laid against str. 5D-22-4th-B; cf. No. 17). Excavated as 12P-Lots 21 and 29. Randomly occurring fill charcoal identified as hardwood. Cimi ceramics abundant in these and other contemporary lots; information on degree or earlier admixtures lacking. A date of ca. A.D. 175 would be reasonable for the building of 26-3rd. The radiocarbon result is much too old, suggesting PH and possibly PSG as causes of the discrepancy.

\section{P-567. North Acropolis, Ref. No. 19}

$$
2107 \pm 63
$$

157 B.c.

Tikal, North Acropolis, thick fill or ballast of Floor 6 which abuts Str. 5D-26-3rd and covers its substructure (cf. No. 18) and abuts Str. 5D22-4th-A (cf. No. 17). Excavated as 12P-Lots 22 and 23. Cimi pottery is the latest material within these and/or stratigraphically equivalent lots; Cauac admixture occurs. The randomly occurring charcoal bits are identified as hardwood. Sequence and No. 17 lead to an estimated date of ca. A.D. 190 for the laying of Floor 6 (cf. No. 26). The $\mathrm{C}^{14}$ result is far too early for this event and would indicate the extent to which $\mathrm{PH}$ and probably PSG are operable.

\section{P-571. North Acropolis, Ref. No. 20}

$1625 \pm 60$

Tikal, North Acropolis, Str.. 5D-26-1st, fill of first secondary floor which was laid over raised masonry cap of intruded Burial 22 producing late Early Classic Manik ceramic complex vessels (basal flange bowls, etc.); the floor was also laid over the smashed remains of an Early Classic cache vessel. Excavated as 12H-Lot 27. Sample identified as hardwood. If PSG and PH were not factors in this case, we could apply the result as a lower dating limit for the placement of the important Early Classic Burial 22.

\section{P.569. North Acropolis, Ref. No. 21}

$1308 \pm 49$

Tikal, North Acropolis, fill of heavily razed Str. 5D-20-2nd, sealed by -20-1st; the construction of -2nd correlates with the laying of Floor 2 which is secondary to all North Acropolis Early Classic buildings. Excavated as 121-Lots 17 and 19. Charcoal occurred as small pieces in fill, the ceramic content of which was small and inconclusive. In view of No. 22, a date of ca. A.D. 600, on the borderline between Early and Late Classic, would not be impossible for the construction of -2nd and it is within the 1-sigma date-spread of the result.

\section{P-570. North Acropolis, Ref. No. 22}

$1274 \pm 50$

Tikal, North Acropolis, fallen vault beam, rear room, Str. 5̄D-20-1st, which, with its twin, Str. 5D-21-(1st), was built on Floor 1 and shows a number of Late Classic constructional features, although it carries on 
certain Early Classic ones as well. Collected as 12I-Lot 3. The sample is identified as hardwood, perhaps logwood (Haematoxylon). The sample is believed to consist of outer wood. A construction date of very early 7 th century is preferred and this is permitted within the 1-sigma date-spread of the result.

\section{P-572. North Acropolis, Ref. No. 23}

$1624 \pm 61$

Tikal, North Acropolis, fill of $W$ bench of rear central room of Str. $5 \mathrm{D}-26-1 \mathrm{st}$; the bench was built definitely later than the deposition of No. 20 and during a time of production of Imix complex pottery. Excavated as 12H-Lot 40 . The unweathered Imix sherds and thumbnail-sized pieces of charcoal come from a dark mud fill within the bench. Charcoal identified as hardwood. A date between A.D. 650 and 900 is expectable, assuming duration of about two and one-half centuries for Imix pottery. The radiocarbon result is clearly too early. $\mathrm{PH}$ and possibly PSG have to be invoked to explain this discrepancy. By itself, the result favors Correlation A, but stratigraphic relation to No. 20 must be kept in mind.

\section{P.573. North Acropolis, Ref. No. 24}

$1416 \pm 52$

Tikal, North Acropolis, sealed refill of disturbed Burial 22 (cf. No. 20), Structure 5D-26-1st. Robbery, refilling, and patching over of cut were events definitely postdating the bench providing No. 23. Excarated as 12M-Lot 15. This lot contains considerable charcoal, far in excess of normal incidental inclusions. Physical fits between ceremonial items found on the room floor and in the patched-over tomb refill, as well as other considerations, suggest the act of robbing to be Post classic, that is, after but not long after A.D. 900. The room floors were overlain also by considerable charcoal. The charcoal from the tomb refill is identified as Pinus sp. The radiocarbon result well antedates the expected date for the deposition of the charcoal. Pine is considered to be a relatively shortlived tree. PH is a definite possibility here but details are a matter for speculation (cf. No. 25). Previously published sample P-279 (Pennsylvania V) from Str. 5D-34 of the North Acropolis, is believed to have been deposited at about this time (post-A.D. 900) and under similar conditions of depredation. No. 24 should be evaluated along with No. 25.

\section{P.574. North Acropolis, Ref. No. 25}

$1285 \pm 52$

Tikal, North Acropolis, central beach of rear central room of Str. 5 D-26-lst and, specifically, from a refilled and rebuilt cut used to rob Burial 22 (cf. No. 24) and to rob a wooden-roofed cist cache made through the latest room floor just prior to building the bench; this same floor sustains the bench that yielded No. 23. Excavated as 12H-Lot 16. Charcoal identified as Pinus sp. It is probable that No. 24 and No. 25 have a common source. Despite the slight difference between them, it is conceivable that charcoal resulted from the burning of the roofbeams of 
the cist. A date of ca. A.D. 700, even 650 , would be entirely acceptable for this cache. We are, however, postulating pine beams, to our mind unexpected but hardly impossible. $\mathrm{PH}$ here must be considerable and this tentative reconstruction of its details may or may not be correct.

\section{P.575. North Acropolis, Ref. No. 26}

$1749 \pm 59$

Tikal, North Acropolis, Str. 5D-26-1st, E room, hearth and partial human skeleton (disarticulated) partly on the room floor and partly on collapsed vault material. The charcoal, which was plentiful and concentrated in a small area of in situ burning, presumably a hearth, was identified as simply hardwood. Excavated as 12H-Lot 21. Since the sources of Nos. 24 and 25 were beneath similar collapsed vaulting in the central room, it was expected that the hearth dated even later in Postclassic times. A date in the twelfth or thirteenth century seemed likely for the deposition of No. 26. Comment: result, perhaps a millennium too early, forces us to rely on PH and possibly PSG to account for the discrepancy. If we knew the charcoal to be zapote or logwood, we might assume Postclassic use of timber from 26-1st as firewood, and this seems the most probable explanation. A construction date of A.D. 250 for 26-1st is supported by the fact that it occupies the same stratigraphic position as Str. 5D-23-1st, which has provided three dates (Ralph and Stuckenrath, 1962), all from vault beams: P-294, 295, and 296. The results are, respectively, A.D. $602 \pm 52,208 \pm 50$, and $232 \pm 61$. The latter two are interpreted with other evidence as indicating original construction Ca. A.D. 250, while the first would then reflect substitution of a new beam. It is not impossible that Early Classic vaulted buildings were being constructed by ca. A.D. 250 at Tikal, as 23-1st and 26-1st each overlies an earlier version and these four, among others, rest on Floor 5 which is estimated to have been laid early in the 3rd century A.D. In turn laying of this floor probably postdates by a very small interval the appearance of Early Classic elements in the Tikal ceramic inventory.

General Comment: one result of this review is that most of these dates make sense. Admittedly, we have done everything possible to make them fall into a sequential pattern. However, results that fall beyond, both above and below, the X-line in Fig. 1 cannot be simply rejected. Those below the line are old for reasons specifiable, among others, as PSG, PH, and probably, in some cases, X. Doubtless, more would fall so had we additional radiocarbon dates. No 1 is a case in point: we estimated (and found) 600 в.c. as a date falling within the production span of Eb ceramics, but a radiocarbon result pointing to 800 B.c. would not have dumbfounded us. Date-spreads within 1-sigma that fall above the line (too young) require different explanations. Only Nos. 5 and 9 occur above this line and only No. 9 seriously so. Intrusion of these samples (and all others) is precluded by the record. Although we invoke contamination to explain this discrepancy, this is evasive since we really have no idea 
of what it may consist. Nine of the samples fall significantly below the line, while only one lies above it.

Twenty-five of the results are from the stratigraphically well-controlled North Acropolis (the reader must take this on faith until full publication appears). Twenty-four of these are derived from a relatively rapid sequence. Actually, only 11 of the later, however manipulated, express what we hoped they would when the samples were submitted. If, among the samples from ceramically Preclassic sources, we had submitted only Ños. 8, 15, 18 and 19, a distorted chronological scheme would have emerged. The point is that somewhat less than $50 \%$ of the North Acropolis samples make the depositional sense expected of all. This may be a useful statistic; it may be that at other complex sites half the results on charcoal are merely useful for detecting error in the other half.

Most of the samples were excavated by the writer. For instance, in the excavation of No. 23, I could detect nothing that would deny a true, temporal association of context (a masonry bench), sherds, and charcoal. The charcoal and freshly broken sherds occurred in a mud fill. The charcoal was recovered as small but easily extractable pieces, not as wispy specks that required a penknife to remove. In submitting the charcoal, I was hoping to get a date on benches at Tikal that, almost without exception, are secondary additions during the time-span of the Imix ceramic complex. Imix ceramics could not have been made during a time indicated by the radiocarbon results if we accept Correlation B. I see nothing at Tikal, either in its known sequence or in the general run of radiocarbon results that points to the validity of any other correlation. In submitting No. 23, I felt confident that PH was insignificant (as in the case of No. 12). I was wrong, and the experience is humbling as well as informative.

Throughout this review I have been willing to accept, when at all reasonable, the results handed me by the laboratory. I realize that anyone can make what he wishes (fortunately, within certain limits) of the results given here.

Date list:

$\begin{array}{ll}\text { Arizona I } & \text { Wise and Shutler, 1958 } \\ \text { Arizona III } & \text { Damon and Long 1962 } \\ \text { Pennsylvania III } & \text { Ralph, 1959 } \\ \text { Pennsylvania V } & \text { Ralph and Stuckenrath, 1962 } \\ \text { Pennsylvania VI } & \begin{array}{l}\text { Stuckenrath, 1963 } \\ \text { Pennsylvania VIII }\end{array} \\ \text { Stuckenrath and Ralph, 1965 } \\ \text { Yale VI } & \text { Stuiver and Deevey, 1961 }\end{array}$

Benoit, Fernand, 1961, L'Epave du Grand Congloue a Marseilles: Paris, CNRS. 1962, Nouvelles epaves de Provence III: Gallia, v. 20, p. 153.

Borns, F. W., Jr., 1965, Late glacial ice-wedge casts in northern Nova Scotia, Canada: Science, v. 148, no. 3674, p. 1223-1226.

1966, The Paleo-Indian's geography of Nova Scotia: Paper read at Internat.

Assoc. Quaternary Research, 7th, Boulder, 1965. 
Byers, D. S., 1966, The Debert archaeological project: Paper read at Internat. Assoc. Quaternary Research, 7th, Boulder, 1965.

Clark, D. W., 1966, Perspectives in the prehistory of Kodiak Island, Alaska: Am. Antiquity, v. 31, p. 358-371.

Coe, W. R., 1965a, Tikal, Guatemala, and emergent Maya civilization: Science, v. 147, p. 1401-1419.

1965b, Tikal: ten years of study of a Maya ruin in the lowlands of Guatemala: Expedition, Bull. Univ. Mus., Univ. Pennsylvania, v. 8, no. 1, p. 4-56.

Coe, W. R., and McGinn, J. J., 1963, Tikal: the North Acropolis and an early tomb: Expedition, Bull. Univ. Mus., Univ. Pennsylvania, v. 5, no. 2, p. 24-32.

Coe, W. R., and Stuckenrath, Robert, Jr., 1965, A review of La Venta, Tabasco, and its relevance to the Olmec problem: The Kroeber Anthropol. Soc. Papers, No. 31, Univ. California, Berkeley.

Collins, H. B., 1956, The T-1 site at Native Point, Southampton Island, N.W.T.: Anthropol. Papers Univ. Alaska, v. 4, no. 2.

1957, Archaeological investigations on Southampton and Walrus Island, N.W.T.: Ann. Repts. Natl. Mus. Canada, 1955-56, Bull. 147.

Damon, P. E., and Long, Austin, 1962, Arizona Radiocarbon dates III: Radiocarbon, v. 4 , p. $239-249$.

Dyson, R. H., Jr., 1958, Iran, 1957, iron age Hasanlu: Bull. Univ. Mus., Univ. Pennsylvania, v. 22, p. 25-32. 1959, Digging in Iran: Hasanlu, 1958: Expedition, Bull. Univ. Mus., Univ. Univ. Pennsylvania, v. 1 , no. 3 , p. 4-17.

1960a, Death of a city: Expedition, Bull. Univ. Mus., Univ. Pennsylvania, v. 2 , no. 3 , p. $2-11$.

1960b, Hasanlu and early Iran: Archaeology, v. 13, p. 118-129.

1962, The Hasanlu project: Science, v. 135, p. 637-647.

Giddings, J. L., 1952, Driftwood and problems of Arctic sea currents: Proc. Am. Phil. Soc., v. 96 , no. 2 , p. 129-142.

Harp, Elmer, Jr., 1951, An archaeological reconnaissance of the Strait of Belle Isle area: Am. Antiquity, v. 16, p. 203-220.

Kohler, E. L., and Ralph, E. K., 1961, $\mathrm{C}^{14}$ dates for sites in the Mediterranean region: Am. Jour. Archaeol., v. 65, p. 357-367.

Langsdorf, Alexander, and McCown, D. E., 1942, Tall-i-Bakun A, season of 1932: Oriental Inst. Proc., v. 59.

Lamboglia, Nino, 1958, La nave romana di Spargi (la Maddalena); campagna di scavo 1958: Cong. di Archaeol. Sottomarina, 2nd, Albenga, 1958, p. 143-166.

LeBreton, Louis, 1957, The early period at Susa, Mesopotamian relations: Iraq, v. 19, pt. 2, p. 79-125.

MacDonald, G. F., 1966, Artifacts of the Debert site: Paper read at Internat. Assoc, Quaternary Research, 7th, Boulder, 1965.

Maxwell, M. S., 1962, Pre-Dorset and Dorset sites in the vicinity of Lake Harbour, Baffin Island, N.W.T.: Natl. Mus. Canada, Bull. 180, Contrs. Anthropol., 1960, pt. 1.

McCown, D. E., 1955, The relative stratigraphy and chronology of Iran; in Relative Chronologies in Old World Archaeology: Chicago, Univ. Chicago Press, p. 56.

Meldgaard, Jorgen, 1960, Prehistoric culture sequences in the eastern Arctic as elucidated by stratified sites at Igloolik: Internat. Cong. Anthropol. and Ethnol. Sci., 5th, Philadelphia, 1956, Selected Papers: Philadelphia, Univ. Pennsylvania Press.

Mellink, M. J., 1964, Excavations at Karatas-Semayuk in Lycia, 1963: Am. Jour. Archaeol., v. 65, p. 269-284.

Pendergast, D. M., 1965, Maya tombs at Altun Ha: Archaeology, v. 18, p. 210-217.

Rainey, F. G., and Ralph, E. K., 1959, Radiocarbon dating in the Arctic: Am. Antiquity, v. 24, p. 365-375.

Ralph, E. K., 1959, University of Pennsylvania radiocarbon dates III: Am. Jour. Sci. Radioc. Supp., v. 1, p. 45-58. 
1965, Review of radiocarbon dates from Tikal and the Maya calendar correlation problem: Am. Antiquity, v. 30, p. 421-427.

Ralph, E. K., and Stuckenrath, Robert Jr., 1962, University of Pennsylvania radiocarbon dates V: Radiocarbon, v. 4, p. 144-159.

Satterthwaite, Linton, and Ralph, E. K., 1960, New radiocarbon dates and the Maya correlation problem: Am. Antiquity, v. 26, p. 165-184.

Stein, Sis: Aurel, 1937, Archaeological reconnaissances in northwest India and southeastern Iraq: London, Oxford Press, p. 167, pt. 24.

Stuckenrath, Robert, Jr., 1963, University of Pennsylvania radiocarbon dates VI: Radiocarbon, v. 5, p. 82-103.

1964, The Debert site: early man in the northeast: Expedition, Bull. Univ. Mus, Univ. Pennsylvania, v. 7, no. 1, p. 20-29.

1966, The Debert site: radiocarbon dating: Paper read at Internat. Assoc Quaternary Research, 7th, Boulder, 1965.

Stuckenrath, Robert, Jr., and Anderson, D. D., 1966, C ${ }^{14}$ dates for the North American Arctic: Am. Antiquity, v. 31.

Stuckenrath, Robert, Jr., and Ralph, E. K., 1965, University of Pennsylvania radiocarbon dates VIII: Radiocarbon, v. 7, p. 187-199.

Stuiver, Minze, and Deevey, E. S., 1961, Yale natural radiocarbon measurements VI: Radiocarbon, v. 3, p. 126-140.

Taylor, E. W., 1959, Review and assessment of the Dorset problem: Anthropologica, n.s., v. 1.

Weinberg, G. D., Grave, V. R., Edwards, G. R., Robinson, H. S., Throckmorton, Peter, and Ralph, E. K., 1965, The Antikythera shipwreck reconsidered: Trans. Am. Phil, Soc., n.s., v. 55, pt. 3.

Wise, E. N., and Shutler, Dick, Jr., 1958, University of Arizona radiocarbon dates: Science, v. 127, p. 72-74. 